\title{
MAXIMISING STAKEHOLDER VALUE IN PERSONAL INSOLVENCY (A NEW ZEALAND PERSPECTIVE)
}

BY

QUENTIN STOBART HAINES

\author{
A thesis \\ submitted to the Victoria University of Wellington \\ in fulfilment of the requirements for the degree of \\ Master of Laws
}

Victoria University of Wellington

(2015) 


\section{CONTENTS}

Abstract

I Introduction

II Approaches to Insolvency Law 10

A Economic Approach $\quad 10$

B Balanced Approach $\quad 12$

C The Humanitarian Approach $\quad 14$

D Conclusion $\quad 15$

III Identification of Stakeholders in Personal Insolvencies 15

A The Debtor 16

$1 \quad$ Changing debtor profile $\quad 16$

B Creditors 18

$1 \quad$ Secured creditors $\quad 19$

2 Priority creditors 20

3 Unsecured creditors 20

4 Student loans 20

C The Official Assignee $\quad 21$

D Additional Factors for Consideration $\quad 22$

$1 \quad$ The business community 22

$2 \quad$ The moral public 23

E Identification of Stakeholders $\quad 23$

IV New Zealand's Current Insolvency Regime 23

A History 24

B The Unique Current New Zealand Law 26

C Current Options in New Zealand 26

D Current Alternatives to Bankruptcy 27

$1 \quad$ Summary instalment orders $\quad 27$

2 No asset procedure 28

$3 \quad$ Compositions and proposals 29

E Arguments for Personal Administration 30

$1 \quad$ Statistics 31

V Chapter $13 \quad 33$

A Chapter 13 Process 33 
B The Chapter 13 Plan 36

C Chapter 13 and the Court 38

D Discharge from Chapter $13 \quad 39$

E Failure to Complete a Chapter 13 Plan 39

F Secured Creditors and Chapter $13 \quad 41$

G Stakeholders and Chapter $13 \quad 46$

H Conclusions on Chapter 13

$\begin{array}{lll}\text { VI Gateways } & 47\end{array}$

A Introduction $\quad 47$

B Types of Gateways $\quad 48$

C Gateways in Practice - Continental Europe 48

$1 \quad$ France 48

2 Sweden 50

3 Denmark 51

$4 \quad$ Germany $\quad 52$

D United States of America $\quad 52$

E Australia and New Zealand 53

F Trends in Gateways $\quad 55$

G Gateways and Stakeholders $\quad 56$

H Conclusion $\quad 57$

VII Insolvency Solutions for New Zealand 58

A Introduction 58

B Suspension of Proceedings $\quad 59$

C Alternatives to Bankruptcy 61

D The Gateway into Personal Insolvency 62

E $\quad$ Proposed Wording of Statute for Entry into Personal Insolvency 63

F Ease of Entry 64

G The Second Gateway 68

$\begin{array}{lll}H & \text { Stakeholders } & 68\end{array}$

I Liquidated Bankruptcy with Discharge 70

J Objections to Discharge $\quad 71$

K Fresh Start, Can it Fail to Rehabilitate?

L Immediate Discharge $\quad 75$

M Support for Immediate Discharge 76

N Traditional Three Year Discharge 79

VIII Personal Administration $\quad 80$

A The Concept of Personal Administration 81 
B The Process of Personal Administration $\quad 82$

$1 \quad$ Entry $\quad 82$

$2 \quad$ Statement of affairs $\quad 83$

$3 \quad$ Official assignees report $\quad 84$

$4 \quad$ Creditors meeting $\quad 84$

$5 \quad$ Official assignee must approve the personal administration proposal 86

$\begin{array}{lll}C & \text { Judicial Support } & 87\end{array}$

D Secured Creditors $\quad 88$

E Theoretical Support $\quad 89$

F Examples of Personal Administration $\quad 91$

$1 \quad$ Example 1-consumer insolvent 91

2 Example 2-consumer insolvent who suffers a health 92 problem

3 Example 3-the failed business 92

$4 \quad$ Summary of examples 93

$\begin{array}{lll}\text { IX Conclusion } & 94\end{array}$

Bibliography 96 


\section{Abstract}

Personal insolvency law in New Zealand has had some recent amendments that have been successful in reducing the number of bankruptcies. With the rise in consumer bankruptcies and insolvencies, both in New Zealand and internationally many historic insolvency laws and practices are outdated.

Balancing the obligations of debtors with the relief of a proactive insolvency regime while satisfying stakeholders is difficult. If relief is too easily accessed there is a risk of abuse of the system. If relief is too difficult to obtain there will be unnecessary suffering and a potential loss of economic motivation for the insolvent.

A new model of personal administration is argued as the best mechanism for maximising stakeholder value. Such a system if entered through a restrictive gateway would cease any concern of abuse.

\section{7 words excluding footnotes 35514 words including footnotes}




\section{Introduction}

The purpose of my thesis is to examine the personal insolvency systems in New Zealand from the perspective of stakeholder value maximisation. The results of this examination are then compared and contrasted with other real alternative options like the US system of personal administration as contained in chapter 13 of its bankruptcy code and theoretical models. The extrapolated findings are used to determine whether New Zealand should adopt a version of a personal administration scheme or some other form of insolvency alternatives.

New Zealand's insolvency legislation is a tale of the haves and have nots. Corporate insolvency has many well defined processes and options open to the corporate insolvent. It benefited from consistent lobbying from various special interest groups. The net result is that New Zealand enjoys a modern corporate insolvency regime that is in line with its nearest trading partner Australia. Personal insolvency on the other hand has not enjoyed the same level of special interest treatment. Instead New Zealand's personal insolvency regime is antiquated and remains largely the same as it was a century ago. The reforms of the Insolvency Act 2006 started to address the growing issue of consumer bankruptcy.

The lack of political will to address issues in personal insolvency is obvious and universal (except for the US who have been pioneers in this area). The politics of bankruptcy law reform has allowed bankruptcy systems "to decay due to political inertia, this being an area in which politicians show little interest or understanding"1. The issues of personal insolvency should be addressed despite the inherent challenges. This thesis examines the current insolvency regimes in New Zealand and questions whether a system of personal administration should be adopted in New Zealand along with broader reforms of the regime.

In order to tackle this key question, personal insolvency needs to be understood. For the purposes of my thesis, I take the view that personal insolvency involves more than just the simple relationship between debtor and creditor. It involves many stakeholders who are all influenced by self interest. These stakeholders must interact within a framework underpinned by a variety of legal doctrines and statutes which are in turn shaped by practical economics ${ }^{2}$ which includes the concept of wealth maximisation. However in cases of insolvency the concept of wealth maximisation is inverted so that loss mitigation becomes the prevailing concept.

\footnotetext{
${ }^{1}$ Joseph Spooner "Long Overdue: What The Belated Reform of Irish Insolvency Law Tells Us About Comparative Consumer Bankruptcy” (2012) 86 Am. Bankr. L.J. 243 at 247.

${ }^{2}$ Helen Anderson, "Creditors Rights of Recovery: Economic Theory, Corporate Jurisprudence and the Role of Fairness” (2006) 30 Melbourne U. L.R. 1.
} 
Economic theory struggles to deal with the personal insolvency, while the majority of economic scholars have focused on the corporate aspect of creditor rights to recover unpaid debts. Personal insolvency in the post Global Financial Crisis world has far reaching consequences and therefore deserves robust academic research.

In assessing the appropriateness of a personal administration scheme this thesis will adopt an argument based on utility. Stakeholders as a collective group will best mitigate their losses and therefore maximise their returns on personal insolvent estates if a utilitarian approach is adopted. A personal administration regime that offers ease of entry and a clean slate discharge will be championed as the best sort of regime, whether this is achieved through personal administration or an alternative or a combination of alternatives forms the heart of this thesis. Economic theory about resource optimisation and economic efficiency arguments will be used to support this position.

Nebulous concepts of morality and fairness will be juxtaposed against legal doctrine, economic theory ${ }^{3}$, the humanitarian approach $^{4}$, the balanced approach ${ }^{5}$, market mechanics and stakeholder value maximisation. It will be argued that the time old link between debt and morality has been severed since the liberalization of English bankruptcy laws. The Insolvency Act 1976 (UK) introduced the concept of automatic discharge from bankruptcy with a clean slate for the first time. The regime in the US with its codified Bankruptcy $\operatorname{Code}^{6}$ also indicates a clear separation of this link. These will be considered the birth of this separation, the developed US regime will be considered in detail.

This thesis contains the starting premise that a personal administration system rather than bankruptcy will achieve value maximisation for stakeholders and that by adopting a balanced approach greater economic certainty can be created.

The first section of this thesis will discuss the various approaches to personal insolvency law. The three main approaches discussed are those of the economic theory, the balanced approach and the humanitarian approach. The balanced approach will be further refined to develop a new approach, being that of stakeholder value

\footnotetext{
${ }^{3}$ Thomas Jackson, The Logic and Limits of Bankruptcy Law (Harvard University Press Cambridge, Massachusetts, 1986).

${ }^{4}$ Karen Gross, Failure and Forgiveness: rebalancing the bankruptcy system (Yale University Press, New Haven, Connecticut 1997)

${ }^{5}$ John King, "Moving beyond the hard-easy tug of war: a historical, empirical and theoretical assessment of bankruptcy discharge" (2004) 28 Melbourne U. L.R. 654 at 676.

6 11 U.S.C. $\$ \S 101-1532$.
} 
maximisation. This new approach will be argued as the actual approach used by the courts when assessing insolvency cases.

The second section will identify the relevant stakeholders. Their respective interests will be explained using economic theory. Creditors will be divided into three distinct groups: those who are secured creditors, priority creditors and those who are unsecured creditors. The difference in risk assessment tools and ability to factor risk into the pricing of creditor goods and services will be analysed.

Debtors will also be examined. The statistical demographics of the average insolvent in New Zealand will be discussed along with the changing nature of this profile. Debtors fall into two broad categories: consumer debtors and business debtors. These categories can be further developed to understand where the debtor sits on the debt spectrum, are they a debtor, insolvent or are they bankrupt? The various types of debtors and creditors are discussed along with other relevant parties to develop a list of individuals who make up the stakeholders to an insolvency.

The third section discusses the current New Zealand insolvency regime and the development of the insolvency legislation over time. Particular focus will be given to the alternatives to bankruptcy that are contained within the Insolvency Act 2006. The alternatives of proposals, compositions and compromises are discussed along with the No Asset Procedure and the Summary Instalment Orders. The lack of a personal administration system in New Zealand is argued as being a major flaw.

The fourth section looks at the different personal administration regimes that are prevalent in other key jurisdictions. The US Chapter $13^{7}$ personal administration model is examined in considerable detail. The focus on the Chapter 13 regime as a potential starting point is based on the fact that it is the most mature of all of the regimes available for comparative analysis. The limitations of the Chapter 13 model are also discussed. The contradictions contained within the scheme are exposed along with the conflicting and contradictory nature of many of the key provisions. The amendments to Chapter 13 from 2005 called the "Bankruptcy Abuse Prevention and Consumer Protection Act" (BACPA) are also discussed in some detail. It is argued that this amendment has detracted some of the usefulness of the underlying legislation.

The fifth section focuses on gateways to insolvency regimes. This issue is important as many issues are created by the ease or difficulty in accessing insolvency and bankruptcy regimes.

\footnotetext{
${ }^{7} 11$ U.S.C. $\S \S 1301-1331$.
} 
The sixth section examines a number of alternatives that either exist currently in statute or have been raised by other scholars. These alternatives try to reconcile economic theory, legal doctrine, morality, fairness and insolvency law. This is done through the use of economic theory, where each transaction or part thereof seeks to obtain efficiency. This is where each party "reach[es] an agreement which allocates their respective rights and entitlements in a way that is satisfactory to both parties and maximises the total output of the transaction." "It is argued that increasing the role, scope and power of the office of the Official Assignee will add new efficiencies to the system by diverting processing matters away from the Court.

In order to instil confidence and transparency within the proposed changes a gateway model is proposed. This gateway takes the individual from being a debtor through certain procedural processes so that individual is given a different legal status. For the purposes of this paper that different legal status has been referred to as "personally insolvent". In this legal state of suspense they are examined by the Official Assignee prior to commencing down any of the recommended pathways. Using the utilitarian, humanitarian and economic theories together, a variety of recommendations for personal insolvency reform are made. These reforms include: 'Velvet Bankruptcy' as mooted by David Hahn', options for early discharge of bankrupt's with a clean slate, greater use of existing compromise and composition provisions contained in the Insolvency Act 2006.

The seventh section will focus on my version of personal administration. This system will incorporate a voluntary administration regime pre bankruptcy that is administered by the State through the office of the Official Assignee. This has been described above as the individual being personally insolvent. Such a scheme would be positioned as a precursor to bankruptcy which would be initiated by the Court without delay once an act of bankruptcy has been committed. The scheme would incorporate the filing of a 'statement of affairs' and an examination of the individual by the Official Assignee. The results of this examination would then be shared with all creditors at a meeting where a set of recommendations about a compromise scheme would be put forward by the Official Assignee for creditor input, although the Official Assignee would be granted the power to implement the scheme regardless of creditor opinion. There would exist mechanisms whereby the Official Assignee would be obliged to hear creditor concerns. If creditor objections resulted in the Official Assignee deciding not to proceed with the proposal or if the Official Assignee found

\footnotetext{
${ }^{8}$ Anderson, above n.2 at 18.

9 David Hahn, "Personal Bankruptcy in the $21{ }^{\text {st }}$ Century: Emerging Trends and New Challenges:

Velvet Bankruptcy” (2006) 7 Theoretical Inq. L. 533.
} 
misconduct on the part of the debtor then the Official Assignee would be obliged to channel the insolvent into a bankruptcy alternative.

\section{Approaches to Insolvency Law}

This section provides a brief examination of some of the leading theoretical approaches to insolvency law. King adopts two dominant normative approaches in his work on bankruptcy law, termed; 'the economic approach' and 'the balanced approach' ${ }^{10}$. He argues that the balanced approach provides a greater good for debtors, creditors and his nebulous 'community'. This balanced approach is argued as being the best approach for evaluation of amendments to the New Zealand insolvency regime. This balanced approach is further refined so a new approach is developed. This new approach is termed stakeholder value maximisation. It is essentially a subset of the balanced approach and will be used as the benchmark for assessing the current insolvency regime and also reviewing the proposed reforms.

\section{A Economic Approach}

Thomas Jackson, a proponent of the economic approach, suggests "bankruptcy law is a response to credit". ${ }^{11}$ If there was no credit given then there would be no purpose for insolvency legislation. However there is credit; lots of credit, in fact an entire industry is based on credit and that industry funds most of the civilised world and its production and consumption. The basic principle of credit is that a debtor borrows against their future income, potentially using some form of asset as collateral for the loan.

This system works incredibly well as long as the debtor is able to continue to make payments. When a debtor is unable to make payments insolvency occurs. Jackson argues that bankruptcy law is primarily focused on a compulsory collective system for satisfying the claims of creditors. Bankruptcy becomes a cooperative device to allow creditors, who may be a diverse group, to work collectively to share in the insolvent's estate. The alternative would be each creditor operating independently to pursue their own remedy. ${ }^{12}$

The economic theory is based on the presumption that the lenders have a better understanding of the potential risks of credit than debtors. Creditors are therefore

\footnotetext{
${ }^{10}$ King, above n 5, at 677.

${ }^{11}$ Jackson, above $\mathrm{n} 3$ at 7.

${ }^{12}$ At 14.
} 
better placed to carry the risk/burden of insolvency of a debtor. If a bankruptcy occurs, it is ultimately the creditor who suffers the loss if the bankrupt estate falls short. Economic theory claims that the cost of this potential loss is factored into the cost of the credit. ${ }^{13}$

Discharge from bankruptcy does give the bankrupt a fresh start and extinguishes the creditor's collection remedies. This discharge according to the economic theory, is acceptable because it is priced into the cost of credit and the bankrupt has contributed all of their non-exempt assets to the bankrupt estate. By both parties sharing some of the risks an equilibrium occurs. Creditors maintain responsibility for monitoring their lending and debtors balance their consumption with their income. Economic theory argues that if discharge becomes too easy then the cost of credit has to increase and its availability has to become more selective. Conversely if the discharge provisions become too onerous, people would become more cautious and would not avail themselves of credit, thereby upsetting the equilibrium of the credit economy.

It is argued that the economic approach is too narrow in its assessment of insolvency situations. The fundamental problem with the economic approach as stated by Donald Korobkin is: ${ }^{14}$

[I]n narrowly seeking to explain bankruptcy law as a mechanism for achieving economic outcomes, the economic account has prevented itself from locating what truly makes bankruptcy law distinct. Most importantly, because of its focus on corporate insolvency, the economic approach does not address the discharge provisions and the accompanying fresh start provisions

This focus on the economic problem of bankruptcy is a one dimensional view of a set of much larger issues. Whilst debt collection and distribution of the bankrupt's estate to creditors are an important aspect of insolvency law and function they represent only one part of the function.

\footnotetext{
${ }^{13}$ Thomas Jackson, “The Fresh Start Policy in Bankruptcy Law” (1984-1985) 98 Harvard L.R. 1393 at 1399.

${ }^{14}$ Donald Korobkin, "Rehabilitating Values: A Jurisprudence of Bankruptcy" (1990) 91 Columbia Law Review at 739.
} 
The alternative approach as put forward by King is the balanced approach, which "must equitably balance the interests of creditors, debtors and the community." 15 This view represents a paradigm shift from the economic approach to encompass the full gambit of issues. Many commentators argue that this approach is the dominant approach of modern bankruptcy law. Steven Harris argues "that bankruptcy law in large measure seeks to accommodate a number of societal values at the time when the debtor is in financial difficulty." 16 Karen Gross has developed a conceptual theory that bankruptcy is a "three legged stool." ${ }^{17}$ This concept is expanded by King as follows: ${ }^{18}$

Each leg [of the three legged stool] represents a group of interests - those of debtors, creditors and the community. The support of all three legs is crucial, and all are interconnected. Similarly, an ideal bankruptcy system will equitably balance all three interests: the debtor would have a fresh start, creditors would be paid in an economically efficient manner, and community interests would be preserved.

This concept of equitable balance is a theoretical ideal that any proposed reform should aspire to. The reality is that like many theoretical ideals it could prove elusive to achieve.

Economic theory can still support this balanced approach and economic efficiency can still be achieved. The generally accepted measure of economic efficiency is Kaldor-Hicks analysis. ${ }^{19}$ This analysis involves resource allocation in a manner whereby the "benefit to those who are better off exceeds the harm to those that are worse off." 20

Taking this balanced approach and extending into the wider philosophical framework of a utilitarian philosophy an ideal fit is created. "If the benefit to society outweighs the detriment to the individual, the overall result is seen as fair." 21

\footnotetext{
${ }^{15} \mathrm{King}$, above n 5 at 676.

${ }^{16}$ Steven Harris, "A Reply to Theodore Eisenberg's Bankruptcy Law in Perspective" (1982) 30 UCLA

L.R. 364.

${ }^{17}$ Gross, above $\mathrm{n} 4$.

${ }^{18} \mathrm{King}$, above n 5 at 677.

${ }^{19}$ This is named for Nicholas Kaldor, "Welfare Propositions of Economics and Interpersonal Comparisons of Utility" (1939) 49 Economic Journal 549, and John Hicks, "The Foundations of Welfare Economics" (1939) 49 Economic Journal 696.

${ }^{20}$ Ian Ward, An Introduction to Critical Legal Theory ( $\left.1^{\text {st }} \mathrm{ed}, 1998\right) 129$.

${ }^{21}$ Daniel Farber, "What (if Anything) Can Economics Say about Equity?" (2003) 101 Mich. L. Rev. 1791.
} 
"Conversely, it is unfair to recognise the rights of one person if that harms the wellbeing of the rest of society." 22

Since the basis of insolvency law accepts that there is going to be a loss for at least some parties, a utilitarian approach which focuses on the greatest good or the least harm is the most practical framework when a balanced approach is taken. However this approach still has one major short coming in that it is nigh impossible to measure harm or benefit. M D A Freeman notes: ${ }^{23}$

One of the problems with utilitarianism is the lack of a method for calculating the effect of a decision or policy on the total happiness of a relevant [population]. It [also] offers no reliable technique for measuring change in the level of satisfaction of one individual relative to a change in the level of satisfaction of another.

Philosophers and economists have long since vigorously defended this shortcoming by usurping the decision back to the sovereign. In the case of an insolvency in New Zealand the Official Assignee would be best positioned to decide on what is 'fair' based on the individual facts of each insolvency. Parliament would provide the legislative framework so the Official Assignee had guidance on what Parliament considered the correct way to interpret 'fairness'. Jason Neyers makes the following comment on fairness in a wealth redistribution scenario: ${ }^{24}$

Of relevance to our discussion is the fact that fairness is often used to refer to how wealth is distributed in society. So unlike efficiency, fairness in concerned with the end effect of wealth distribution... Also, fairness in our legal tradition assumes support for those who are vulnerable and the meeting of people's reasonable and legitimate expectations.

The concept of fairness within a utilitarian system can further be expanded to include the views of the various stakeholders to the insolvency. Anderson states: ${ }^{25}$

In terms of economic teleology, an outcome is both Kaldor-Hicks efficient as well as fair and just if it brings about a net benefit to society, even though some people may be much worse off. The rights of the individual are set aside in pursuit of a 'greater good', so that a result that is Kaldor-Hicks efficient in economic terms is fair in legal terms.

\footnotetext{
${ }^{22}$ Anderson, above $\mathrm{n} 2$ at 18.

${ }^{23}$ M D A Freeman Lloyd's Introduction to Jurisprudence ( $7^{\text {th }}$ ed, 2001) 557.

${ }^{24}$ Jason Neyers, "Canadian Corporate Law, Veil-Piercing and the Private Law Model Corporation" (2000) 50 University of Toronto Law Journal at 213.

${ }^{25}$ Anderson, above $\mathrm{n} 2$ at 18.
} 
Karen Gross, a leading proponent of the humanitarian approach, looks further than the simple debtor creditor relationship and takes a holistic view of society as a whole. ${ }^{26}$ If the only players were the debtor and the creditor Gross argues that the creditor would go to extreme lengths to pursue the debtor. Even after the debtor had sold all of their assets and there was an on-going shortfall the creditor would still keep pursuing the debtor. This in theory could create a situation of permanent indebtedness which the debtor could never escape from. This would cause the debtor to give up hope and they could cease to be a productive member of society.

It is also recognised that under the humanitarian approach there are other factors to be considered. Penney notes that there are other factors at play: ${ }^{27}$

The inability to repay money borrowed represents larger issues and failures, not just of the debtor, but of society as a whole. These failures include those in industries, education and health systems, families as well as the lending system. The fact that one cannot meet their debts may be the result of something that is beyond their control. A failure in any aspect of a person's life may result in an inability to meet ones financial obligations.

Gross takes issue with many of the current bankruptcy regimes for not providing a variety of different treatments of bankrupts based on their personal circumstances and their culpability in their financial distress. The humanitarian approach is based around rehabilitation of the bankrupt. There is a broad assumption that there must have been a failure of some sort for the bankruptcy to occur. This failure may or may not be within the control of the bankrupt, for example ill health. The discharge with a fresh start is just part of the rehabilitation process according to Gross. $^{28}$

Both the economic and the humanitarian theories arrive at the same general conclusion that discharge from bankruptcy is a good thing for creditors, debtor and society as a whole. ${ }^{29}$ While both theories reach this conclusion through differing processes of analysis they share some common themes. A credit economy can only operate efficiently in conjunction with a robust insolvency regime: a debtor is more valuable to society if they are able to make a positive contribution and will only be motivated to do so should a discharge occur. As a result of this positive contribution, society as a whole benefits from the discharge. The bankrupt has paid the price for the fresh start through the bankruptcy.

\footnotetext{
${ }^{26}$ Gross, above n 2 at $14-24$.

${ }^{27}$ Jane Penney, Discharge of Bankrupts: Recent Developments (Law Faculty Victoria University,

Wellington, 2008) at 20.

${ }^{28}$ Gross, above n 4 at 131.

${ }^{29}$ Penney, above n 27 at 24.
} 
Although stakeholders" respective interests undoubtedly compete, there may exist a compromise solution that is fair and acceptable to all. Such a solution may in fact be a mechanism for extracting maximum value for all stakeholders to the insolvency. This refinement of the balanced approach provides the concept of stakeholder value maximisation. Although not a traditional concept in its own right, the Court has shown that it has tried to perform such a balancing of stakeholder interests in New Zealand insolvency cases. Most of these cases are in respect of discharge objections where the interests of the following parties/interest groups are weighed up by the Court: the insolvent's interests, the creditor's interests, the public interest, commercial morality and the conduct of the insolvent. ${ }^{30}$ It is through adopting this balancing of various competing stakeholder interests that value maximisation occurs.

\title{
III Identification of the Stakeholders in Personal Insolvencies
}

This chapter sets out to identify the relevant stakeholders whose interests should be balanced. Traditional literature on personal insolvency is focused on the relationship between debtor and creditor and on the moral views of the public in general. As Douglas Boshkoff: states: ${ }^{31}$

\begin{abstract}
Any bankruptcy law must, of necessity, be an accommodation between competing interests that include the creditor's desire to be paid, the debtor's desire to escape a burdensome situation, the value society places on having people pay their debts in full, and the value society places on allowing debtors to start anew when overtaken by financial misfortune.
\end{abstract}

John King discusses the "interests of creditors, debtors and the community" 32 but fails to provide any identification of 'the community'. This lack of concise identification of all relevant stakeholders limits a full examination of insolvency law and its impact to society in general. This section sets out to expand on King's approach by identifying relevant stakeholders to insolvencies. These stakeholders will be the cornerstones of the proposed reforms outlined in the latter stages of this thesis. The motivation of each stakeholder is also discussed in order to provide a deeper level of understanding of their respective stake in the insolvency.

\footnotetext{
${ }^{30}$ Brookers Online, “Commentary Insolvency Law \& Practice” Brookers Online http://www.brookersonline.co.nz.helicon.vuw.ac.nz/databases/modus/lawpart/statutes/ACT-NZL-PUBY.2006-55 BDY PT.4 SPT.1 SG.!101 S.298?si=57359 last viewed 26 February 2014.

${ }^{31}$ Douglass Boshkoff, "Limited, Conditional, and Suspended Discharges in Anglo-American Bankruptcy Proceedings"” (1998) 131 U. Pa. L. Rev. 69 at 125.

${ }^{32}$ King, above n 5 at 676.
} 
For the purposes of this paper, the concept of the debtor is broken down into three general categories: a debtor refers to an individual who owes a debt to a creditor, an insolvent refers to any debtor who has failed to pay their debt to a creditor as it falls due or has committed an 'Act of Bankruptcy' as defined by the Insolvency Act $2006^{33}$, a bankrupt refers to an individual who has been bankrupted by either debtor or creditor petition.

Each category of debtor can be further divided based on their conduct. King notes from an Australian perspective: ${ }^{34}$

Currently, a distinction is made between a bankrupt who has committed fraudulent conduct ('fraudulent bankrupt') and other bankrupts ('unfortunate bankrupt'). There are numerous practical problems in even this seemingly simple distinction. Nevertheless, Australian bankruptcy law distinguishes between these two types of bankrupts in administrative and discharge processes. An unfortunate bankrupt can expect a brief and nonintrusive administration and a standard discharge... By contrast, a fraudulent bankrupt can expect a rigorous administration designed to expose any commercially culpable conduct and is likely to have discharge delayed.

King also notes in his work a third type of bankrupt being the reckless bankrupt. The reckless bankrupt can be its own category or a sub-category of the fraudulent bankrupt depending on the prevailing fact scenario.

\section{$1 \quad$ Changing debtor profile}

There are essentially two broad categories of debtor; the business debtor/failed entrepreneur, and the consumer debtor. One of the driving forces behind the Insolvency Act 2006 was a recognition that the profile of the average bankrupt had changed since the Insolvency Act 1967. Fleur Baker and Ralph Simpson observed: ${ }^{35}$

The changing make-up of a "typical bankrupt" means that the regime is no longer providing an effective solution for the majority of debtors and creditors. This is largely related to the increase in people who become bankrupt due to consumer credit related issues, as opposed to the high

\footnotetext{
${ }^{33}$ Insolvency Act 2006, ss16-28.

${ }^{34}$ King, above n 5 at 663.

${ }^{35}$ Fleur Baker and Ralph Simpson, Creditors' Remedies (Continuing Legal Education Department of the New Zealand Law Society, 2001).
} 
number of sole-trader bankrupts when the law was last reviewed in the 1960s.

(a) Consumer debtors

The modern debtor is a consumer debtor. A consumer has been defined by the Consumer Guarantees Act 1993 as follows: ${ }^{36}$

consumer means a person who-

(a) acquires from a supplier goods or services of a kind ordinarily acquired for personal, domestic, or household use or consumption; and

(b) does not acquire the goods or services, or hold himself or herself out as acquiring the goods or services, for the purpose of-

(i) resupplying them in trade; or

(ii) consuming them in the course of a process of production or manufacture; or

(iii) in the case of goods, repairing or treating in trade other goods or fixtures on land

It is reasonable for the purpose of this paper to adopt this definition for a consumer. Although there are other definitions of a consumer in other New Zealand legislation, this definition allows for clear differentiation from a business debtor. Any consumer debtor or consumer bankrupt must be an individual who has acquired their respective debts or obligations for the purpose of supporting their consumption.

The statistical profile of the modern bankrupt will typically be: a New Zealand European $\left(54 \%{ }^{37}\right)$, male $(61 \%)^{38}$, aged between 40 and $44(17 \%)^{39}$ and unemployed ${ }^{40}$.

The other debtor type is the business debtor/failed entrepreneur which shall now be discussed.

(b) The failed entrepreneur or business debtor

A failed entrepreneur is simply a debtor who incurred their obligations through a business or a commercial debt being unable to be repaid. Incorporation has allowed entrepreneurs a risk taking vehicle to carry out commercial operations. By using such a vehicle the concepts of limited liability would in theory protect the entrepreneur from personal liability from an honest business failure. The doctrine of

\footnotetext{
${ }^{36}$ Consumer Guarantees Act 1993, s2(1).

${ }^{37}$ Insolvency and Trustee Service Insolvency Statistics and Debtor Profile Report for the Year 1 July 2012 to 30 June 2013, (Insolvency and Trustee Service, New Zealand, 2013) at 11.

${ }^{38}$ At 11 .

${ }^{39}$ At 11.

${ }^{40}$ At 11 .
} 
limited liability that was concisely articulated in Salomon ${ }^{41}$ has been recognised as one of the foundations of corporate law. The uptake of the use of incorporation has grown considerably over the last century.

"Limited liability comes with a cost. It harbours the hazard of entrepreneurs engaging in overly risky business activities. This is called overinvestment." 42 The blanket protection offered to an entrepreneur who incorporates, shifts the entire risk of the venture to the creditors. Yet the majority of the benefit if the venture succeeds flows to the entrepreneur. This is clearly an imbalance that encourages entrepreneurs to the detriment of creditors.

The growth in the use of limited liability incorporations has also lead to a situation where entrepreneurs who want to avail themselves of credit for a project have to provide a personal guarantee. David Hahn notes: ${ }^{43}$

\begin{abstract}
A personal guarantee undertaken by a shareholder exposes that shareholder to the guaranteed corporate lender. Against this creditor, the guarantee effectively reverses the principle of limited liability. The corporate and personal bankruptcy laws determine the extent of debt that the corporation and its guarantor-shareholder will ultimately have to pay the creditor upon the insolvency of the corporation.
\end{abstract}

This circumvention of the doctrine of limited liability exposes the potential entrepreneur to considerable additional personal risk. Therefore "the theoretical premise of limited liability as an entrepreneur-friendly feature of incorporation is simply outdated." 44

\title{
B Creditors
}

In order to be a creditor to an insolvency, a creditor has to have a debt that is provable. The Insolvency Act 2006 describes a provable debt as: ${ }^{45}$

\section{What debts are provable debts}

(1) A provable debt is a debt or liability that the bankrupt owes-

(a) at the time of adjudication; or

\footnotetext{
${ }^{41}$ Salomon v Salomon \& Co [1897] AC 22.

42 Hahn, above $\mathrm{n} 9$ at 528 .

${ }^{43}$ At 524.

${ }^{44}$ Charles Tabb, "The Scope of the Fresh Start in Bankruptcy: Collateral Conversions and the Dischargability Debate" (1990) 59 Geo. Wash. L Rev. 56 at 100.

${ }^{45}$ Insolvency Act 2006, s 232.
} 
(b) after adjudication but before discharge, by reason of an obligation incurred by the bankrupt before adjudication.

(2) A fine, penalty, sentence of reparation, or other order for the payment of money that has been made following any conviction or order made under section 106 of the Sentencing Act 2002-

(a) is not a provable debt; and

(b) is not discharged when the bankrupt is discharged from bankruptcy.

Creditors, like debtors can also be divided into several subgroups of stakeholder. The first division of creditors should be between those that hold a security and those that do not.

\section{$1 \quad$ Secured creditors}

Banks and other professional lenders, including trade creditors understand the risks of default from a borrower. Banks have invested heavily in systems and processes so as to assess an individual's credit worthiness prior to providing any credit. Lenders also have the ability to price their credit based on the perceived risk of a given venture. Banks are also able to spread their potential losses or mitigate them entirely through insurance and personal guarantees. Further, through their size and diversified "customer [base], banks are the most efficient risk-bearers of the [debtors] defaults." 46

These professional lenders often are also secured, meaning that their debt is attached in some form to the debtor's property. This can either be achieved through a registered mortgage, caveat or a registered security on the securities register. By holding a security a creditor has additional options over unsecured creditors for debt collection. The Insolvency Act 2006 provides: $^{47}$

\section{Secured creditor's options in relation to property subject to charge}

(1) A secured creditor may-

\footnotetext{
${ }^{46}$ Frank Easterbrook \& Daniel Fischel, The Economic Structure of Corporate Law (Harvard University Press, 1991).

${ }^{47}$ Insolvency Act 2006, s 243.
} 
(a) realise property subject to a charge, if entitled to do so (Option 1); or

(b) value the property subject to the charge and prove in the bankruptcy as an unsecured creditor for the balance due (if any) after deducting the amount of the valuation (Option 2); or

(c) surrender the charge to the Assignee for the general benefit of the creditors and prove in the bankruptcy as an unsecured creditor for the whole debt (Option 3).

(2) Despite subsection (1), a secured creditor may exercise Option 1 whether or not the creditor has exercised Option 2.

A creditor holds a priority or a preferential claim to be paid by virtue of the Insolvency Act $2006^{48}$. Some priorities of note are: the Official Assignee for carrying out the administration of the bankruptcy ${ }^{49}$, the petitioning creditor for their costs (if there was a petitioning creditor) ${ }^{50}$, and the Commissioner for Inland Revenue ${ }^{51}$. A priority creditor holds a priority over unsecured creditors without priority. Being a priority creditor does not provide any certainty of recovery of the debt. If there is some recovery of the debt it is managed by the Insolvency Act $2006^{52}$.

\section{$3 \quad$ Unsecured creditors}

An unsecured creditor is a creditor that holds no security and has no priority under the Insolvency Act $2006^{53}$. Unsecured creditors are only entitled to a dividend if there are funds left after payment of secured and priority creditors.

\section{$4 \quad$ Student loans}

Since the inception of the Student Loans Scheme ${ }^{54}$ in New Zealand, the Ministry of Social Development has become a substantial creditor. Jane Penney observes: ${ }^{55}$

\footnotetext{
${ }^{48}$ Insolvency Act 2006, s 274.

${ }^{49}$ Section s 274(1)(a).

${ }^{50}$ Section s 274(1)(b).

51 Section 274.

${ }^{52}$ Sections $274-279$.

${ }^{53}$ Section 280.

${ }^{54}$ Student Loan Scheme Act 1992.
} 
New Zealand is one of the only jurisdictions in which student loans are provable in bankruptcy. In the United Kingdom, the United States and Canada student loans are not provable debts. Two reasons are given to support this. The first is that students would abuse the bankruptcy system in order to free themselves of these debts before embarking on lucrative careers. The second reason is the need to protect the public interest. In all jurisdictions except the United States student loans are government loans.

\section{Parliament has also legislated a level of priority to student loans ${ }^{56}$. Penney notes: ${ }^{57}$}

The Queen acting through the Minister of Social Security is the lender and at the end of each loan year the balance is transferred to the Commissioner of Inland Revenue for collection. Thus student loans are crown debts. This results in student loans being paid above other unsecured debts.

Student Loans are a provable debt in bankruptcy. They like all other provable debts are dealt with by the Insolvency Act 2006. Student Loans because of their unique nature do warrant specific mention.

\section{The Official Assignee}

The office of the Official Assignee has no connection with the debtor or the insolvent. However the moment an adjudication of bankruptcy occurs either by debtor or creditor petition the Official Assignee becomes involved. The Official Assignee's role is to administer the bankruptcy regime in New Zealand. The powers of the Official Assignee are contained in the first Schedule of the Insolvency Act 2006. ${ }^{58}$ These powers are wide ranging and allow the assignee to deal with the bankrupt's estate. Section 64 of the Insolvency Act outlines the process on adjudication: ${ }^{59}$

64 Outline of what happens on adjudication

(1) On adjudication-
(a) the Assignee must advertise the adjudication; and
(b) the bankrupt must file with the Assignee a statement of his or her
affairs, if the bankrupt has not already done so; and
(c) the Assignee may call a meeting of the bankrupt's creditors; and
(d) proceedings to recover certain debts must be halted; and

\footnotetext{
55 Penney, above $\mathrm{n} 27$ at 25.

${ }^{56}$ Student Loan Scheme Act 1992, s 4.

${ }^{57}$ Penney, above n 27 at 27.

${ }^{58}$ Insolvency Act 2006. Schedule 1.

${ }^{59}$ Section 64.
} 
(e) the property of the bankrupt vests in the Assignee.

(2) This section is a guide only to the immediate consequences of adjudication.

Notwithstanding the lack of involvement of the Official Assignee prior to adjudication it is clear that its role is pivotal in the administration of the bankruptcy regime, and therefore must be classified as a stakeholder. Further the Official Assignee incurs expenses on behalf of the bankrupt estate for its administration, these fees are also ranked as a preferential debt in compositions. If a composition is reached during bankruptcy the Official Assignees' fees must be paid prior to court approval. ${ }^{60}$ The reforms proposed in later chapters increase the involvement of the Official Assignee in the management of insolvencies in New Zealand.

\section{Additional Factors for Consideration}

As discussed already there is an identified need for entrepreneurship within the economy. The generation of extra tax receipts, employment and export dollars are all benefits to the economy and the business community. The business community must have a level of certainty about the interactions of different parties for its effective operation. Rules must exist and be obeyed, otherwise a level of economic anarchy would descend.

\section{$1 \quad$ The business community}

This group has peripheral interest in individual insolvencies. Whenever possible the risk is factored into the price of goods and services. The business communities' interest is in the upholding of commercial law, legal doctrine and the concept of certainty within the context of business dealings. It is acknowledged by Stephen Bainbridge that the theoretical "'Economic Man'; the 'autonomous individual who makes rational choices that maximise his satisfactions' would be 'a feral monster with no partners and no customers." "61 This is clearly not the reality of the commercial world. Instead there must exist an underlying level of trust between all economic players for a capitalist system to function. Part of that trust exists through having fair, reliable and transparent insolvency procedures.

\footnotetext{
${ }^{60}$ Section 317(3).

${ }^{61}$ Stephen Bainbridge, "Community and Statism: A Conservative Contractarian Critique of Progressive Corporate Law Scholarship” (1997) 82 Cornell L. Rev. 856 at 871.
} 
As stated previously there exists a strong swell of public opinion that debtors do not just abandon their debts and that bankruptcy has an element of moral failing

attached to it. Challenging these social stereotypes is not easy; Joseph Spooner ${ }^{62}$ argues that bankruptcy regimes suffer from political apathy or worse, political avoidance, with no politician wanting to be seen as championing the cause of bankrupts.

The moral public rationalises its position with the logic 'if I have to pay my debts then why shouldn't everybody else?' There is of course no easy answer to this question and philosophical and academic debate still surrounds this exact question. Equally the moral public wants to protections for the vulnerable from unscrupulous creditors and lenders, hence the Credit Contracts and Consumer Finance Act 2003.

\section{E Identification of Stakeholders}

After analysis of the 'debtor, creditor and community' summary provided by King $^{63}$, it is quite clear that the stakeholders in a bankruptcy are numerous. Each stakeholder sits with a unique perspective on the insolvency with its own individual vested interests in the outcome of the process. Therefore any meaningful discussion on bankruptcy or possible alternatives to it must address the interests of the stakeholders. The identified types of stakeholders to New Zealand insolvencies are: debtors, insolvents, bankrupts, secured creditors, priority creditors, unsecured creditors, the office of the Official Assignee and the general public.

\section{New Zealand's Current Insolvency Regime}

This chapter examines the current and historical legislation relating to insolvency law. The purpose of this examination is to identify potential gaps in the current alternative. By looking at the historical developments in insolvency, normative features of the regime can be identified. Further by observing the statistical trends in the type and demographics of insolvents it is possible to suggest amendments that are highly relevant to the changing face of the New Zealand insolvent.

\footnotetext{
${ }^{62}$ Spooner, above $\mathrm{n} 1$.

${ }^{63}$ King, above n 5 .
} 
Most law in New Zealand has its root in English law and insolvency law is no exception. Therefore to understand the history of insolvency law in New Zealand, a brief examination of English Law is required. The purpose of the examination of the historical developments of insolvency law in New Zealand is to demonstrate a historical precedent for compositions or other arrangements where creditors receive less than the full amount that they are owed.

"From the mid sixteenth century, until the early seventeenth century, the Privy Council, in its executive role, actively worked to assist debtors in financial difficulties" ${ }^{\circ 4}$ with compositions. Heath and Whale noted that the Privy Council: ${ }^{65}$

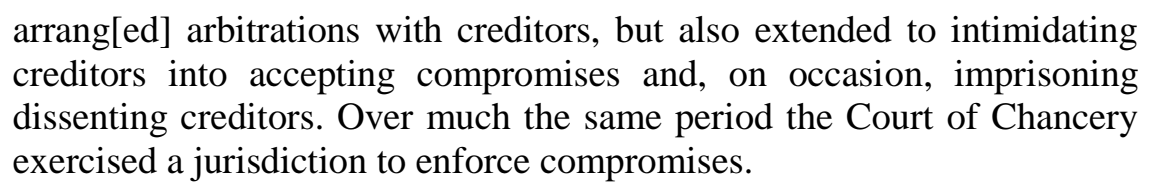

In 1697 the concept of compositions made their first appearance in legislation with the $1697 \mathrm{Act}^{66}$. This legislation allowed debtors to bind creditors if a majority of two thirds was reached. This legislation was repealed about a year later because of the prevalence of fraud on the part of debtors in stacking the creditor numbers in their favour.

Over the next century there was no legislative recognition of compositions. The Bankruptcy Consolidation Act of $1825^{67}$ restored compositions as a legislated alternative to bankruptcy. Compositions have remained in all insolvency legislation since this time in English law, and were directly imported to New Zealand law with the Bankruptcy Act $1883^{68}$.

The Bankruptcy Consolidation Act of $1825^{69}$ provided a very high threshold requirement based on the number of creditors and percentage of debt. Support in excess of $90 \%$ in number of creditors and value of debt was required in order to bind creditors. In examining the rationale for this Treiman noted "it was aimed not at

\footnotetext{
${ }^{64}$ Israel Treiman, "Majority Control in Compositions: Its Historical Origins and Development" (1937) Va. L. Rev. 507.

${ }^{65}$ Paul Heath and Michael Whale, Insolvency Law in New Zealand (LexisNexis, Wellington, 2011) at 240.

${ }^{66} 1697$ Act, 8, 9 Will III, cl 8.

${ }^{67}$ Bankruptcy Consolidation Act 1825 (UK).

${ }^{68}$ Bankruptcy Act 1883.

${ }^{69}$ Bankruptcy Consolidation Act 1825 (UK) 6 Geo IV, cl 6.
} 
giving effect to the wishes of the majority of creditors, but rather preventing a small minority from blocking the composition."70

Under all of the New Zealand Insolvency Acts ${ }^{71}$ since 1883 compositions have only been allowed once bankruptcy had been adjudicated (meaning they were not alternatives to bankruptcy but rather a mechanism for achieving early discharge or annulment). The Insolvency Act of $1967^{72}$ with the addition of Part XV added a prebankruptcy composition alternative for the first time. The wording of Part XV appears to be a duplication of the wording used for post-bankruptcy compositions. These pre bankruptcy compositions are referred to as 'proposals' in New Zealand legislation.

The long history of both pre and post-bankruptcy compositions demonstrates a normative approach towards compositions within a cultural context. It would also be a reasonable proposition that compositions were deemed to be an acceptable alternative to bankruptcy from the perspective of all stakeholders. Accordingly there appears to have never been any lobbying to remove compositions as a legislated option. In fact the opposite appears to be the case in that more alternatives to bankruptcy are being added in each of the last two Insolvency Acts. ${ }^{73}$

Company legislation in New Zealand also contains direct reference to compromises in Part 14 of the $\mathrm{Act}^{74}$ and voluntary administration in Part $15 \mathrm{~A}^{75}$, both of which are potential alternative forms of debtor relief. These additional pieces of legislation also support the proposition that stakeholders accept that in some circumstances alternatives to insolvency need to exist.

The historical acceptance of compositions as being a mode for Court sanctioned debt relief is well established. Further the evolution of New Zealand law has demonstrated a preference for compositions to be reviewed by the Court at a time when the debtor is bankrupt. This achieves the result that all compositions presented to the Court are presented by individuals who are already under the control of the Official Assignee. The Court then has the benefit of the full report of the Official Assignee $^{76}$ prior to any decision being made.

\footnotetext{
70 Treiman, above n 60 at 523-524.

${ }^{71}$ New Zealand has had new insolvency legislation in the Acts of 1892, 1908, 1967 and 2006.

72 Insolvency Act 1967.

${ }^{73}$ Insolvency Act 1967 added Part XV Proposals and the Insolvency Act 2006 added, 'No Asset Procedure" and "Summary Instalment Orders".

${ }^{74}$ Companies Act 1993, s227.

${ }^{75}$ Companies Act 1993, s 239A

${ }^{76}$ Insolvency Act 2006, s 296.
} 
Personal insolvency law in New Zealand is antiquated compared to many other first world countries. New Zealand is one of the few jurisdictions to operate a dual system of insolvency regimes in that it has a system for personal insolvency separate from that of corporate insolvencies ${ }^{77}$. The Law Commission recommended in its 2001 report that the "collection of all insolvency law under one umbrella statute has appeal: such a statute is likely to promote both accessibility to and comprehension of, the law"78 This recommendation was not followed. The logic for not following this was that "a single statute would be large and complex, with superficial semblance of order." 79 Thus New Zealand continues to operate a dual system notwithstanding the Law Commission recommendations.

\section{Current Options in New Zealand}

In order to understand the current alternatives to bankruptcy in New Zealand an understanding of bankruptcy itself should first be established. Section 7 of the Insolvency Act provides the following commentary: ${ }^{80}$

7 Nature of Bankruptcy

(1) Bankruptcy affects the legal status of a person and has important consequences. These include-

(a) The bankrupt's property vests in the Official Assignee:

(b) The bankrupt is limited in the business activities he or she can undertake:

(c) The Official Assignee may be entitled to recover assets that the bankrupt has transferred before bankruptcy.

(2) This section is intended only as a guide to the consequences of bankruptcy.

As $\mathrm{s7(2)}$ notes this is a guide only to the consequences and a full reading of the Act and Regulations should be performed in order to gain a fuller understanding.

When the current changes were first mooted in the Insolvency Reform Bill which was introduced on 21 December 2005, the Bill contained an Explanatory Note that the objectives of the new statutes were to: ${ }^{81}$

(i) Provide a predictable and simple regime for financial failure that can be administered quickly and efficiently, imposes the minimum necessary compliance and regulatory

\footnotetext{
${ }^{77}$ Section 6. Also see Companies Act 1993.

${ }^{78}$ New Zealand Law Commission, "Insolvency Law Reform: Promoting Trust and Confidence" An Advisory Report to the Ministry of Economic Development, Study Paper 11, Wellington, (2001), p112.

${ }^{79}$ Ministry of Economic Development Draft Insolvency Law Reform Bill Discussion Document Wellington, (2004), p51.

${ }^{80}$ Insolvency Act, s 7.

${ }^{81}$ Insolvency Law Reform Bill 2005 (No 14-1) (Explanatory Note, General Policy Statement) at 1.
} 
costs on its users and does not stifle innovation, responsible risk taking, and entrepreneurialism by excessively penalising business failure;

(ii) Distribute the proceeds to creditors in accordance with their relative pre insolvency entitlements, unless it can be shown that the public interest in providing greater protection to one or more creditors outweighs the economic and social costs of any such priority;

(iii) Maximise the return to creditors by providing flexible and effective methods of insolvency administration and enforcement which encourage early intervention when financial distress becomes apparent;

(iv) Enable individuals in bankruptcy to participate again fully in the economic life of the community; and

(v) Promote international co-operation in relation to cross boarder insolvency.

It is argued that this demonstrates Parliament's intention to maximise value for all stakeholders. The current insolvency legislation in New Zealand offers a range of alternatives to bankruptcy that are all contained in the legislation. A discussion of these alternatives now follows.

\section{Current Alternatives to Bankruptcy}

The Insolvency Act 2006 bought in two new alternatives to bankruptcy: the no asset procedure ${ }^{82}$ and the summary instalment order. ${ }^{83}$ The uptake of these two alternatives now accounts for approximately a third of all insolvency cases in New Zealand $^{84}$.

\section{$1 \quad$ Summary instalment orders}

The summary instalment order relates to unsecured debts of up to $\$ 40,000$ and is accessed by a simple process that does not involve the Court. Entry into the scheme is by direct application to the Official Assignee. To be eligible for the summary instalment order a debtor must be in the required debt limits and be unable to immediately pay those debts. ${ }^{85}$ The procedure can be initiated by either a debtor or a creditor, with the debtor's consent. ${ }^{86}$ The application must be in the prescribed form and be accompanied by payment of the fee of $\$ 100^{87}$. It is an interesting aside that this fee is the only fee that is charged under the Insolvency Act 2006 for applications of insolvency relief. There appears to be no substantial commentary on the rational for a fee being payable for only summary instalment orders.

\footnotetext{
${ }^{82}$ Sections $361-377 \mathrm{~B}$.

${ }^{83}$ Sections $340-360$.

${ }^{84}$ Insolvency and Trustee Service, above n 37 at 2.

${ }^{85}$ Insolvency Act 2006, s 343(1).

${ }^{86}$ Section 341.

${ }^{87}$ Section 342(2).
} 
Although the application is filed with the Official Assignee, the debtor may nominate a supervisor who will oversee the program ${ }^{88}$. If the debtor does not provide the details of a suitable individual to act as the supervisor, the Official Assignee can perform the role. ${ }^{89}$ As soon as practicable after filing with the Official Assignee all creditors must be notified of the order. Creditors then have 10 days to make submissions to the Official Assignee about the proposed order. ${ }^{90}$ The nature of the application does not have to allow for full payment of all debts, covered by the proposed order but it must clearly state the proposed dividend. ${ }^{91}$

On an order being made by the Official Assignee, the supervisor must send a notice to all creditors. ${ }^{92}$ The order may contain direction that the debtor's wages are to be garnished by their employer and paid directly to the supervisor..$^{93}$ The supervisor's role and function are set out in the Act and the Regulations. ${ }^{94}$

Creditors are estopped from taking further legal or enforcement actions. The District Court is required to cease any proceeding, upon receiving notice of an order. ${ }^{95}$ If a debtor defaults in making any of the payments due under the order, ceased proceedings can be continued. ${ }^{96}$ This provides a considerable incentive for debtor compliance with the order.

\section{$2 \quad$ No Asset Procedure}

The no asset procedure has been developed as an efficient mechanism for dealing with debtors who have no assets. The no asset procedure is akin to a mini bankruptcy that only lasts a maximum of 12 months prior to discharge ${ }^{97}$. The aim of the no asset procedure was to, according to Brown, "provide first time bankrupts with a fresh start without the stigma attached to bankruptcy. ${ }^{98}$

To be eligible for the no asset procedure a debtor has to have between $\$ 1,000$ and $\$ 40,000$ of debt, no assets (except those allowed by the legislation) and no means

\footnotetext{
${ }^{88}$ Section 342(2)(c)

${ }^{89}$ Section 342.

${ }^{90}$ Insolvency (Personal Insolvency) Regulations 2007, reg 44(5).

${ }^{91}$ Section 342(2)(a)

${ }^{92}$ Section 342.

93 Section 344.

${ }^{94}$ Section 346 and Insolvency (Personal Insolvency) Regulations, regs $59-64$.

${ }^{95}$ Section 352(3).

${ }^{96}$ Section 359.

${ }^{97}$ Section 377(1).

${ }^{98}$ David Brown and Thomas GW Telfer, Personal and Corporate Insolvency Legislation: Guide and Commentary to the 2006 Amendments (Lexis Nexis NZ Ltd, Wellington, 2007) at 28.
} 
to repay their debts along with never being bankrupt previously. ${ }^{99}$ To enter the scheme the debtor has to complete a statement of affairs in the prescribed form. ${ }^{100}$ The debtor is deemed to have been accepted into the procedure when the Official Assignee sends the debtor a written notice. ${ }^{101}$ On being accepted into the procedure all creditors are estopped from proceeding or commencing enforcement procedures. ${ }^{102} \mathrm{~A}$ key differentiating factor between this procedure and bankruptcy is that student loans are not covered by this procedure. ${ }^{103}$

The procedure can come to a conclusion through a variety of different ways: discharge from the procedure at the expiration of the 12 months $^{104}$, the Official Assignee terminates the debtor's involvement in the procedure because of some dishonesty on the part of the debtor ${ }^{105}$, or because the debtor has been adjudicated bankrupt by either debtor or creditor petition. If the debtor has been discharged the debts that were enforceable on entry to the procedure are cancelled and the debtor is discharged of all obligations for any outstanding balance, interest or penalties associated with the debts. ${ }^{106}$

\section{$3 \quad$ Compositions and proposals}

Compositions can only occur post-bankruptcy under the Insolvency Act $2006^{107}$. They are Court sanctioned alternatives for bankrupts to deal with their bankrupt estate. Proposals are Court sanctioned pre-bankruptcy alternatives. Both proposals and compositions must be presented to the Court in a very specific format. There is merit in examining the current wording of what the Court requires prior to approving compositions under section 315 and comparing it with the Court's requirements under section 333 for approving proposals made pre-bankruptcy.

Section 333 expressly acknowledges that a third party trustee will be directly involved in administering the proposal. In contrast section 315 is silent on the subject. It must therefore be assumed that the only party who can act as trustee in those circumstances is the Official Assignee. This would make sense as the applicant under section 315 is already bankrupt.

\footnotetext{
${ }^{99}$ Insolvency Act 2006, s 363.

${ }^{100}$ Section 363(2) and Insolvency (Personal Insolvency) Regulations 2007, reg 65.

${ }^{101}$ Section 367(1).

102 Section 369(1).

${ }^{103}$ Section 369(2)(c).

${ }^{104}$ Section 377.

105 Section 373.

${ }^{106}$ Section 377(2).

${ }^{107}$ Insolvency Act 2006, ss 312 - 324.
} 
The New Zealand Law Commission Report ${ }^{108}$ recommended that the monopoly held by the Official Assignee on managing New Zealand insolvencies come to an end. This did not occur, and the Official Assignee still holds this monopoly under the current Insolvency Act.

Both ss 315 and 333 appear to have the same key steps attached to them, in that there is a requirement:

1. That a proposal has to be presented to creditors;

2. that the required level of vote has been passed by the creditors;

3. that the terms of the proposal/composition are reasonable;

4. that the general body of creditors benefit;

5. that there has been no misconduct on the part of the insolvent;

6. that the proposal is expedient;

7. that the Court finds no other reason to deny the application.

\section{E Arguments for Personal Administration}

Parliament has created legislated alternatives to bankruptcy with the Insolvency Act 2006. The logic for creating these options was based on the "increased trend of bankruptcies and liquidations, with continuing nil or low returns to unsecured creditors." 109 It was against this backdrop that the 2006 Act was developed. Arguably the word has developed rapidly over the last eight years since the last amendments. The international recession known as the "Global Financial Crisis" has occurred along with the rapid development of electronic currency and a continued trend towards consumerism. The traditional profile of the bankrupt of the 1960's being a sole-trader has now morphed into being a consumer. ${ }^{110}$ International trends support the change in the profile of the average international bankrupt becoming increasingly a consumer and not a failed business person. ${ }^{111}$ In order to understand the trends in New Zealand insolvencies an examination of the raw data is now performed.

\footnotetext{
${ }^{108}$ New Zealand Law Commission, "Insolvency Law Reform: Promoting Trust and Confidence: An Advisory Report to the Ministry of Economic Development, 2001, p59.

${ }^{109}$ Fleur Baker and Ralph Simpson, above n 35 at 119.

${ }^{110}$ Fleur Baker and Ralph Simpson, above n 35 at 144.

${ }^{111}$ Kilborne at 1
} 


\section{Statistics}

In reality the uptake of these alternative options has been astounding as the following table of statistics from the Insolvency Office shows: ${ }^{112}$

\begin{tabular}{|c|c|c|c|c|c|}
\hline $\begin{array}{l}\text { Financial } \\
\text { Year Ending }\end{array}$ & $\begin{array}{l}\text { Total } \\
\text { Insolvencies }\end{array}$ & $\begin{array}{l}\text { Debtor } \\
\text { Application }\end{array}$ & $\begin{array}{l}\text { Creditor } \\
\text { Application }\end{array}$ & $\begin{array}{l}\text { No Asset } \\
\text { Procedure }\end{array}$ & $\begin{array}{l}\text { Summary } \\
\text { Instalment } \\
\text { Order }\end{array}$ \\
\hline 94 & 2274 & 1164 & 1110 & & \\
\hline 95 & 1991 & 994 & 997 & & \\
\hline 96 & 2130 & 1154 & 976 & & \\
\hline 97 & 2458 & 1521 & 937 & & \\
\hline 98 & 2949 & 1867 & 1082 & & \\
\hline 99 & 3285 & 2041 & 1244 & & \\
\hline 00 & 2673 & 1672 & 1001 & & \\
\hline 01 & 2859 & 1946 & 913 & & \\
\hline 02 & 2811 & 1937 & 874 & & \\
\hline 03 & 2800 & 2107 & 693 & & \\
\hline 04 & 2792 & 2220 & 572 & & \\
\hline 05 & 2995 & 2403 & 592 & & \\
\hline 06 & 3087 & 2540 & 547 & & \\
\hline 07 & 3594 & 2890 & 704 & & \\
\hline 08 & 3802 & 1741 & 763 & 1244 & 54 \\
\hline 09 & 5654 & 1660 & 904 & 2833 & 257 \\
\hline 10 & 6426 & 2026 & 1028 & 3026 & 346 \\
\hline 11 & 5596 & 1694 & 1020 & 2514 & 368 \\
\hline 12 & 4640 & 1397 & 1020 & 1872 & 351 \\
\hline 13 & 3950 & 1270 & 918 & 1448 & 314 \\
\hline
\end{tabular}

The key features of this data is firstly the rapid increase in the number of insolvencies across the board in the year ending 30 June 2009. This sudden increase correlates directly with the timing of the global financial crisis. It should also be noted that the figures for the year ending 30 June 2013 appear to return to the pre global financial crisis level of total insolvencies. This data appears to support the assumption that New Zealand has exited the recession.

The second key feature that can be drawn from the data is the strong uptake of the No Asset Procedure. Approximately 37\% of all insolvencies were a No Asset Procedure. Prior to the No Asset Procedure being an alternative, these insolvents would only have found relief through bankruptcy. The popularity of this alternative,

\footnotetext{
${ }^{112}$ Insolvency and Trustee Service Insolvency Statistics and Debtor Profile Report (1 July 2012 to 30 June 2013) at page 2. Able to be viewed at http://www.insolvency.govt.nz/cms/site-tools/aboutus/statistics/statistical-data-reports/ITS-Statistical-Data-Report-12-13.pdf
} 
in large part due, to the size range of debts that it covers $(\$ 1,000-\$ 40,000)$, has seen a direct reduction in the number of bankruptcies without increasing the overall number of insolvencies. The popularity of this scheme is argued, as being the fact that the debt range covered allows for a major proportion of insolvents to be included. In order to prove this point the following comparative table is used to compare insolvency numbers as a percentage of population across the last seven years: ${ }^{113}$

\begin{tabular}{|l|l|l|l|}
\hline \multicolumn{4}{|l|}{ Annual Rate of Personal Insolvency } \\
\hline $\begin{array}{l}\text { Financial Year } \\
\text { Ending }\end{array}$ & $\begin{array}{l}\text { Estimated } \\
\text { Population* }\end{array}$ & $\begin{array}{l}\text { Personal } \\
\text { Insolvencies }\end{array}$ & $\begin{array}{l}\text { Rate of Personal } \\
\text { Insolvencies** }\end{array}$ \\
\hline 07 & $3,321,200$ & 3,594 & $0.11 \%$ \\
\hline 08 & $3,362,100$ & 3,802 & $0.11 \%$ \\
\hline 09 & $3,402,400$ & 5,654 & $0.17 \%$ \\
\hline 10 & $3,452,500$ & 6,426 & $0.19 \%$ \\
\hline 11 & $3,495,900$ & 5,596 & $0.16 \%$ \\
\hline 12 & $3,528,300$ & 4,640 & $0.13 \%$ \\
\hline 13 & $3,579,900$ & 3,950 & $0.11 \%$ \\
\hline & * Estimated resident population aged 15+ & \\
* Rate of personal insolvencies for population aged $15+$ & & \\
\hline
\end{tabular}

These figures clearly demonstrate that apart from the increased number of insolvencies over the period of the global financial crisis, the actual uptake of insolvency relief has remained static, thereby dispelling any theory of floodgates being opened with a more rehabilitative insolvency regime. In fact the argument can be advanced on the statistics that having alternatives for insolvents has actually made the system more efficient, in that a No Asset Procedure takes one year for the Official Assignee to administer compared to the three years a bankruptcy takes to administer.

The proposition advanced in this thesis is that the addition of a personal administration scheme will not increase the number of insolvencies. It will however provide a greater opportunity for creditors to receive a dividend then the current model. The statistics support that the percentage of the population that avail themselves of insolvency relief has not increased by virtue of perceived easy alternatives historically. It therefore stands that any additional reforms to insolvency legislation are unlikely to result in a tide of applications.

\footnotetext{
${ }^{113}$ Insolvency and Trustee Service Insolvency Statistics and Debtor Profile Report (1 July 2012 to 30 June 2013) at page 5. Able to be viewed at http://www.insolvency.govt.nz/cms/site-tools/aboutus/statistics/statistical-data-reports/ITS-Statistical-Data-Report-12-13.pdf
} 


\section{Chapter 13}

In order to be able to suggest alternative approaches to bankruptcy laws in New Zealand, examination of foreign regimes is required. The leading foreign regime is that of the US. Its bankruptcy legislation represents the one of the oldest codified regimes in the world. This thesis does not attempt to provide an in depth analysis of the code but instead uses the code as a 'yardstick' to measure alternative concepts, models and insolvency alternatives. This chapter will focus on the mechanics of Chapter 13 (the US alternative to personal bankruptcy). Entry into the scheme, compliance with the scheme and exit from the scheme are all examined. The involvement of stakeholders is studied with reference to their rights, returns and remedies during the Chapter 13 process. Special discussion is had on the position of secured creditors within the Chapter 13 environment and the effects that the 'cram down' provisions on their respective securities. The important discussion is to what happens when Chapter 13 schemes fail and how they convert to bankruptcy (in the US this is defined and controlled by Chapter 7).

\section{A Chapter 13 Process}

The "Bankruptcy Code" was enacted by Congress in 1978 as a mechanism for dealing with a variety of situations of insolvency. The code covers individual and corporate insolvencies and provides a variety of alternatives for each to consider. The "Bankruptcy Code" has come about by Congress exercising its powers under Article 1, Section 8 of the United States Constitution which authorises Congress to enact "uniform Laws on the subject of Bankruptcies".

Chapter 13 bankruptcies are designed specifically for individuals. Corporations and partnerships are not eligible for Chapter 13 relief, they are dealt with under other parts of the bankruptcy code. Chapter 13 offers a viable alternative to Chapter 7 bankruptcies, which conforms more with the traditional bankruptcy model where most property and chattels are lost. Chapter $13^{114}$ allows insolvents the ability to retain their home and to potentially estop mortgagee sales proceedings if strict criteria are followed. The result can allow the insolvent to resolve mortgage

\footnotetext{
114 Prior to 1993 , bankruptcy judges had the power to cram-down mortgage loans. The prohibition on cram-down of mortgages in bankruptcy is based on the Supreme Court's decision in Nobleman v. American Savings Bank, 508 US 324 (1993) and on 11 U.S.C. § 1322(b)(2), which prevents bankruptcy judges from discharging any mortgage debt secured only by a primary residence, even if the value of the house is below the mortgage principle. 11 U.S.C. §1322(c)(1) allows debtors to cure defaults on their mortgages in Chapter 13, as long as the residence has not been sold in foreclosure.
} 
defaults and arrears within the Chapter 13 plan. The insolvent is still obliged to make all mortgage payments as they fall due during the Chapter 13 bankruptcy period.

The Chapter 13 plan also has an effect on other secured loans in that it allows the insolvent to reset the payment over those loans over the life of the Chapter 13 plan $^{115}$. This alleviates cash flow pressures in that the individual payments reduce in value per payment as they are made over the life of the plan.

The final advantages of the Chapter 13 plan relate to protection of co-debtors, guarantors and co-signatories. These parties are not liable for the debt to be called against them under the Chapter 13 plan $^{116}$. This is a significant benefit of Chapter 13 . By using an independent Trustee to administer the Chapter 13 plan, potential personality issues are removed from the situation. This is because the insolvent makes all their respective payments directly to the Trustee. It is the role of the Trustee to administer the Chapter 13 plan and make all payments under the plan to creditors.

To be eligible for a Chapter 13 bankruptcy an individual has to be a wage earner; being self-employed or operating an unincorporated business is also acceptable. It is the ability to demonstrate a regular income stream that allows for a plan to be developed to pay all or part of the insolvent's debts. This plan usually lasts for between 3 and 5 years depending on the circumstances surrounding the insolvent's income.

In addition to the regular income component the insolvent must also have secured debts of less than $\$ 1,081,400$ and unsecured debts of less than $\$ 360,0475^{117}$. These amounts are adjusted from time to time to reflect movements in the consumer price index. The insolvent is barred from entering a Chapter 13 bankruptcy if they have' in the 180 days prior to filing an application to enter a Chapter 13 arrangement, been in default or failed to comply with any other creditor or debtor initiated bankruptcy proceedings ${ }^{118}$.

The final gateway provision for entry into a Chapter 13 bankruptcy is education. This provision is not limited to Chapter 13 as it applies to all the chapters of the Bankruptcy Code relating to individuals. The insolvent must, within the proceeding 180 day of entering into the plan, attend counselling from an approved credit counselling agency. ${ }^{119}$

\footnotetext{
11511 U.S.C. $\$ 1322(c)(1)$.

11611 U.S.C. $\$ 1301(\mathrm{a})$.

11711 U.S.C. $\$ 109(\mathrm{e})$.

11811 U.S.C. $\$ 109,111$.

11911 U.S.C. $\$ 109(\mathrm{~g})$.
} 
It is argued that the inference from the wording and the general eligibility criteria makes Chapter 13 a rehabilitative process rather than a punitive process. The insolvent is rewarded for making a plan and sticking with it. By adding an educational component to the Bankruptcy Code's eligibility it is clear that Congress is trying to aid insolvents with compliance of the plan and prevent further instances of insolvency in the future.

The actual process of Chapter 13 starts with the insolvent filing a petition with their local Bankruptcy Court. The insolvent is also normally required to file ${ }^{120}$ :

(b) Schedules, STATEMENTS, AND OTHER DOCuMENTS REQUIRED.

(1) Except in a chapter 9 municipality case, the debtor, unless the court orders otherwise, shall file the following schedules, statements, and other documents, prepared as prescribed by the appropriate Official Forms, if any:

(A) schedules of assets and liabilities;

(B) a schedule of current income and expenditures;

(C) a schedule of executory contracts and unexpired leases;

(D) a statement of financial affairs;

(E) copies of all payment advices or other evidence of payment, if any, received by the debtor from an employer within 60 days before the filing of the petition, with redaction of all but the last four digits of the debtor's social-security number or individual taxpayer-identification number; and

(F) a record of any interest that the debtor has in an account or program of the type specified in $\$ 521(\mathrm{c})$ of the Code.

Along with these documents the insolvent must file proof of attending the abovementioned credit counselling program. If the insolvent has developed a plan during the counselling program this should also be filed. On filing, the insolvent must pay the prescribed filing fee and the associated miscellaneous administrative fee. Although these fees are modest (less than $\$ 300$ at the time of writing), it is accepted that the insolvent may not have this money to cover the fees on filing, so there is the

${ }^{120}$ Federal Rules of Bankruptcy Procedure § 1007(b). 
provision for the insolvent to apply to the Court to pay the fees by instalments over a period of time not exceeding 120 days. ${ }^{121}$

If a married couple wish to file a petition for a Chapter 13 plan, they can elect to do so jointly or individually ${ }^{122}$. However if just one party elects to file for Chapter 13 relief full financial details have to be provided for the spouse of the applicant in order for the Court and creditors to understand the financial situation of the household.

Once the petition has been filed with the Court, a Trustee is appointed. This Trustee should be impartial as their role is to administer the Chapter 13 plan. ${ }^{123}$ They also have the role of evaluating the case for the Court along with calling the meeting of all creditors. This creditors' meeting should occur sometime between 21 and 50 days after the filing of the petition with the Court ${ }^{124}$.

The creditors' meeting provides an opportunity for both the Trustee and creditors to examine the insolvent about the circumstances that lead to the insolvency and the plan itself. The insolvent is on oath whilst this examination occurs. ${ }^{125}$

\section{B The Chapter 13 Plan}

Creditors fall into three broad groups for all bankruptcies regardless, of jurisdiction. These groups are: priority creditors, secured creditors and unsecured creditors. For a Chapter 13 plan to be approved by the Court it must deal with all of these groups of creditors correctly as per the Bankruptcy Code.

Priority creditors are those who have a priority claim as prescribed by bankruptcy law. Debts such as taxes and the costs of the bankruptcy proceedings are included in this category. The plan filed by the insolvent must pay all priority creditors in full unless a particular creditor agrees to be treated differently. There are some exceptions such as domestic support obligations which can be dealt with over a five year plan if the insolvent agrees to pay all disposable income under the plan ${ }^{126}$.

Secured creditors are those that hold a security over property or a chattel. If the insolvent wishes to keep the item which is subject to the security, the Chapter 13

\footnotetext{
${ }^{121}$ Federal Rules of Bankruptcy Procedure $§ 1006(b)(2)$.

12211 U.S.C. $\$ 302(a)$.

12311 U.S.C. $\$ 1302$.

${ }^{124}$ Federal Rules of Bankruptcy Procedure $§ 2003(a)$.

12511 U.S.C. $\$ 343$.

12611 U.S.C. $\$ 1322(a)$.
} 
plan must provide that the secured creditor receives at least the value of collateral. However if the loan or financial obligation was entered into shortly before the filing of the petition, the insolvent will be liable to pay the value of the debt rather than the depreciated value of the asset. Secured creditors whose obligations last longer than the proposed plan such as mortgages are still able to be included in the plan notwithstanding the existence of the obligation after discharge. From a practical perspective an agreed rearrangement of the debt and on going obligations is required during the plan.

Unsecured creditors enjoy no such protections under a Chapter 13 plan. The plan need not pay unsecured creditors in full as long as the plan provides for the insolvent paying all "disposable income" over an "applicable commitment period". It is further a requirement that all unsecured creditors receive at least as much as they would under a full Chapter 7 bankruptcy ${ }^{127}$. "Disposable income" is described as ${ }^{128}$.

(2) For purposes of this subsection, the term "disposable income" means current monthly income received by the debtor (other than child support payments, foster care payments, or disability payments for a dependent child made in accordance with applicable nonbankruptcy law to the extent reasonably necessary to be expended for such child) less amounts reasonably necessary to be expended-

(A)

(i) for the maintenance or support of the debtor or a dependent of the debtor, or for a domestic support obligation, that first becomes payable after the date the petition is filed; and

(ii) for charitable contributions (that meet the definition of "charitable contribution" under section 548 (d)(3)) to a qualified religious or charitable entity or organization (as defined in section 548 (d)(4)) in an amount not to exceed 15 percent of gross income of the debtor for the year in which the contributions are made; and

(B) if the debtor is engaged in business, for the payment of expenditures necessary for the continuation, preservation, and operation of such business.

"Applicable commitment period" is defined as ${ }^{129}$ :

(A) subject to subparagraph (B), shall be-

(i) 3 years; or

(ii) not less than 5 years, if the current monthly income of the debtor and the debtor's spouse combined, when multiplied by 12 , is not less than-

\footnotetext{
12711 U.S.C $\$ 1325$.

12811 U.S.C. $\$ 1325(\mathrm{~b})(2)(\mathrm{A})$ and (B).

12911 U.S.C. Section 1325(b)(4).
} 
(I) in the case of a debtor in a household of 1 person, the median family income of the applicable State for 1 earner;

(II) in the case of a debtor in a household of 2, 3, or 4 individuals, the highest median family income of the applicable State for a family of the same number or fewer individuals; or

(III) in the case of a debtor in a household exceeding 4 individuals, the highest median family income of the applicable State for a family of 4 or fewer individuals, plus $\$ 525$ per month for each individual in excess of 4 ; and

(B) may be less than 3 or 5 years, whichever is applicable under subparagraph (A), but only if the plan provides for payment in full of all allowed unsecured claims over a shorter period.

It is curious that the length of time that the insolvent is subject to the Chapter 13 plan is subject to a means test that requires the higher income earner to be in the plan for longer. It is arguable that this creates a level of unfairness, however on closer scrutiny it appears that those that are most able to pay do so, whilst those less able to pay are spared any prolonged hardship that the Chapter 13 plan may create.

\section{Chapter 13 and the Court}

One of the key components of the Chapter 13 regime is that it is subject to judicial scrutiny prior to approval ${ }^{130}$. This important step provides all parties with a level of confidence that the Chapter 13 plan complies with the requisite law, and is therefore in the general interests of the relevant stakeholders as recognised by Congress. Like many Court processes there is a requirement that strict timeframes are adhered to. The insolvent must start making payments to the Trustee within 30 days of filing the petition even if the Chapter 13 plan has not yet been approved ${ }^{131}$. The Court must hold a confirmation hearing within 45 days of the creditors' meeting. ${ }^{132}$ It appears from these timeframes that there is an intended period for the Court and Trustee to be satisfied that the insolvent is honouring the Chapter 13 plan even though it is not yet binding. This clearly provides the Court with a level of comfort as to the workability of the plan and the insolvent's intent to adhere to it.

If the Court does approve the plan, it becomes binding on all creditors no matter which class they are from; equally it is also binding on the insolvent ${ }^{133}$. An important element of the Chapter 13 bargain is the treatment of future unexpected

\footnotetext{
${ }^{130} 11$ U.S.C. $\S 1325$.

${ }^{131} 11$ U.S.C. $\$ 1326(\mathrm{a})(1)$.

13211 U.S.C. $\$ \S 1324,1325$.

13311 U.S.C. $\$ 1327$.
} 
income or other windfalls that the insolvent may receive. The bargain according to Carlson is that the "[insolvent] buys back property of the estate (valued as of the time of the confirmation hearing) in exchange for post-petition income." ${ }^{\text {"134 }}$ Chapter 13 allows for the post-petition income level to change, ${ }^{135}$ therefore any additional income is placed into the plan. Items such as lottery winnings are considered as income so therefore must be contributed to the Chapter 13 plan. On the other hand an inheritance post confirmation is not considered income so the insolvent is able to retain this asset, with no recourse from creditors.

Whilst the insolvent may be able to retain some windfalls post-confirmation they are not able to acquire any further indebtedness. The reasons for this appear to be highly pragmatic, in that the additional debt servicing may compromise the insolvent's ability to honour their commitments as contained in the Chapter 13 plan. Whilst this is not an absolute forbiddance, the insolvent can gain approval of the Trustee if a specific debt is required to be entered into.

\section{Discharge from Chapter 13}

During the course of the Chapter 13 plan the insolvent must make their required payments to the Trustee. For employed individuals it is usual that the contributions are deducted directly from their pay at source; this increases the likelihood of compliance. If the insolvent makes all of the required payments under the Chapter 13 plan, then they are entitled to discharge if they have complied with all of the additional conditions contained within 11 U.S.C. $§ 1328 .{ }^{136}$ If the insolvent has complied then they will be discharged, which releases them from all of their debts contained within the Chapter 13 plan $^{137}$. On discharge, creditors' lose any ability to enforce their debts; in essence the debt is wiped. Discharge marks the end of the Chapter 13 process.

\section{E $\quad$ Failure to Complete a Chapter 13 Plan}

There exists a multitude of reasons that a Chapter 13 plan cannot be completed. The most common one is that the insolvent is unwilling or unable to adjust to the tight budgets that the plan entails. If an insolvent is unable to complete their

\footnotetext{
${ }^{134}$ David Gray Carlson, "The Chapter 13 Estate and Its Discontents" (2009) 17 Am. Bankr. Inst. L. Rev. 233 at 248.

13511 U.S.C. $§ 1329(a)(1)$.

${ }^{136}$ Conditions may include the debtor completing an instructional course concerning personal financial management described in section 111 and not being subject to being charged with any felony.

137 11 U.S.C. $\$ 1328(\mathrm{c})$.
} 
Chapter 13 plan, the insolvent faces the prospect of the plan being converted to a Chapter 7 bankruptcy instead. Chapter 7 bankruptcy is essentially a liquidation bankruptcy in that the insolvent is not able to retain any property or chattels except those few allowed by the Bankruptcy Code.

The conversion from Chapter 13 to Chapter 7 is however unfortunately not as simple as it might seem on the surface. One of the advantages of a codified regime is that it provides a level of certainty; the problem arises when two pieces of the code sit in contrast with each other. Unfortunately this occurs in cases where there is a conversion from Chapter 13 to Chapter 7. The wording contained within 11 U.S.C. $\S$ 1306(a) states ${ }^{138}$ :

(a) Property of the estate includes, in addition to the property specified in section 541 of this title-

(1) all property of the kind specified in such section that the debtor acquires after the commencement of the case but before the case is closed, dismissed, or converted to a case under chapter 7,11 , or 12 of this title, whichever occurs first; and (2) earnings from services performed by the debtor after the commencement of the case but before the case is closed, dismissed, or converted to a case under chapter 7,11 , or 12 of this title, whichever occurs first.

This section in isolation indicates that the property of the Chapter 13 estate contains all of the insolvent's property until discharge occurs. However when this section is compared to 11 U.S.C. $§ 1327$ (b) this states: ${ }^{139}$

(b) Except as otherwise provided in the plan or the order confirming the plan, the confirmation of a plan vests all of the property of the estate in the debtor.

A clear level of confusion can be found when these two sections are placed side by side. This is a legal nullity if the Chapter 13 plan is completed however in instances when it is not there is potential for trouble. Carlson concludes that the key to the discussion is the meaning of the word "vest" and the concept of "vesting". Carlson concludes that "vesting" is a way of saying "transferring absolutely." 140

These differences go beyond pointing to mere drafting peculiarities; they go to key judicial questions on conversion from one form of bankruptcy to another. The importance of these questions relates to the assets just prior to approval of the plan

\footnotetext{
13811 U.S.C. $\$ 1306(\mathrm{a})$.

13911 U.S.C. $\$ 1327(\mathrm{~b})$.

${ }^{140}$ Carlson, above n 134 at 241.
} 
and those assets acquired after the plan have been accepted. Which assets then go on to form part of the Chapter 7 liquidation? The answer is as follows ${ }^{141}$ :

(1) Except as provided in paragraph (2), when a case under chapter $\underline{13}$ of this title is converted to a case under another chapter under this title-

(A) property of the estate in the converted case shall consist of property of the estate, as of the date of filing of the petition, that remains in the possession of or is under the control of the debtor on the date of conversion;

(B) valuations of property and of allowed secured claims in the chapter 13 case shall apply only in a case converted to a case under chapter 11 or 12 , but not in a case converted to a case under chapter 7 , with allowed secured claims in cases under chapters 11 and 12 reduced to the extent that they have been paid in accordance with the chapter 13 plan; and

(C) with respect to cases converted from chapter 13-

(i) the claim of any creditor holding security as of the date of the filing of the petition shall continue to be secured by that security unless the full amount of such claim determined under applicable nonbankruptcy law has been paid in full as of the date of conversion, notwithstanding any valuation or determination of the amount of an allowed secured claim made for the purposes of the case under chapter 13; and

(ii) unless a prebankruptcy default has been fully cured under the plan at the time of conversion, in any proceeding under this title or otherwise, the default shall have the effect given under applicable nonbankruptcy law.

Whilst there exist a number of perplexing contradictions within the Bankruptcy Code there is also enough clarity to allow judicial discretion to achieve a practical outcome. The salient point for the purpose of my thesis is that if a Chapter 13 plan is unable to be completed there is a mechanism for its conversion to Chapter 7.

\section{F $\quad$ Secured Creditors and Chapter 13}

Secured creditors by virtue of holding a security for their respective debt have to be treated differently than their unsecured counterparts. The true power of Chapter 13 lies in the ability of insolvents to deal with secured creditors in a manner that forces their debt to be "crammed down". This subsection takes the time to study the mechanics of Chapter 13 and its treatment of secured creditors, whether the security be held over real property or a chattel the different approaches are discussed.

${ }^{141} 11$ U.S.C. $348(f)$. 
Filing for a Chapter 13 does not directly assist the home owning insolvent. This is because under the law they are still required to repay their mortgages in full or give up their homes. Prior to 1993, bankruptcy judges had the power to cram down mortgage loans secured against the insolvent's principle residence. The Supreme Court's decision in Nobleman ${ }^{142}$ and the wording of 11 U.S.C $\$ 1322(b)(2)$ now restrict this from occurring. The wording of 11 U.S.C $\$ 1322(b)(2)$ states:

(2) modify the rights of holders of secured claims, other than a claim secured only by a security interest in real property that is the debtor's principal residence, or of holders of unsecured claims, or leave unaffected the rights of holders of any class of claims;

These now have the combined effect of preventing the Court from cramming down mortgages secured against principal residences, even in situations where the value of the property is less than the mortgage value ${ }^{143}$. All is not lost for the insolvent as 11 U.S.C. § 1322(c)(1) states the following:

(c) Notwithstanding subsection (b)(2) and applicable nonbankruptcy law-

(1) a default with respect to, or that gave rise to, a lien on the debtor's principal residence may be cured under paragraph (3) or (5) of subsection (b) until such residence is sold at a foreclosure sale that is conducted in accordance with applicable nonbankruptcy law; and

This section provides the following effective relief for the insolvent. Firstly the bank is prevented from taking any further enforcement action. This happens upon the filing of the application with the Court, which prevents the bank from foreclosing on the property. The insolvent is then able to retain their home if they are able to repay the mortgage arrears and make good all on going payments as they fall due. This is all done as part of a payment plan which can last up to five years. Once the arrears have been repaid the original mortgage contract is once again followed. A further benefit of Chapter 13 is that the Trustee has the power to investigate the fees charged by lenders. If the fees are found to be excessive the Trustee may aid the insolvent in challenging these fees. ${ }^{144}$ Porter went further to state that she found that in about half of cases where foreclosure had occurred or was imminent, that questionable or excessive fees had been charged by the lender. The insolvent's cash

\footnotetext{
142 Nobleman v. American Savings Bank 508 U.S. 324 (1993).

${ }^{143}$ Michelle J. White and Ning Zhu, "Saving Your Home in Chapter 13 Bankruptcy" (2010) J. Legal Stud. U. Chi. 33 at 37.

${ }^{144}$ John Eggman, Katherine Porter and Tara Twomey. "Saving Homes in Bankruptcy: Housing Affordability and Loan Modification" (2008) Utah L. Rev. 1123.
} 
flow position is also improved by the filing of a Chapter 13 application. This is because in most cases the insolvent is released from their obligations to unsecured creditors. With this release the insolvent has more disposable cash to meet their mortgage obligations. The essence of this provision means that insolvents are rewarded for having a larger mortgage. For every dollar more of mortgage debt that an insolvent has they are released from a dollar of unsecured debt under the Chapter 13 plan. This was suggested by White and Zhu as an unintended consequence of the 2005 reforms $^{145}$.

Judgement liens are common in the US. As a result many insolvents have liens registered against their property by the time they have to make a decision about filing under the bankruptcy code. Insolvents have a choice under the bankruptcy code as to which chapter they file under. Chapter 13 "provides more options for stripping liens as compared to Chapter 7." ${ }^{146}$ Whereas in contrast White and Zhu observe: ${ }^{147}$

Financially distressed debtors who file for bankruptcy under Chapter 7 receive little help in saving their homes because filing under Chapter 7 does not prevent mortgage lenders from foreclosing or allow debtors to spread out repayment of arrears. However Chapter 7 helps homeowners who do not wish to save their homes because their unsecured debt is discharged and they are not required to repay anything from their future incomes.

This is not to say that an insolvent could not potentially use Chapter 7 to negotiate with their mortgage lenders. However the limitation is that the mortgage arrears usually must be paid in a very short timeframe, and it is therefore unlikely that a lender would grant extensions without being obliged to do so by legislation. Therefore Chapter 13 is known as the "home owner's bankruptcy". Statistics support this statement in that "96 percent of Chapter 13 filers are homeowners and 77 percent of debtors file under Chapter 13 voluntarily" 148 The success rate for filers of Chapter 13 plans according to White and Zhu is around 79 percent. This is obviously a very successful result from an economic and social standpoint. Mortgage lenders are getting repaid their arrears and loans are back on track while society is not burdened with people displaced from their homes and communities are not burdened with foreclosed properties that may be difficult to sell creating a hangout for vagrants.

What is the impact on secured creditors who hold a security over a motor vehicle? Chapter 13 does provide a solution for these creditors. The question at its

\footnotetext{
${ }^{145}$ White and Zhu, above $\mathrm{n} 143$ at 38.

${ }^{146}$ Mark S. Zuckerberg and Amanda K. Quick, "Stripping in Bankruptcy” (2012) 56 Res Gestae Indiana Bar Journal (Indiana State Bar Association December 2012) 39.

${ }^{147}$ White and Zhu, above n 143 at 37.

148 At 37.
} 
root is one of valuation and which valuation technique should be used. In the case of Associates Commercial Corp v. Rash ${ }^{149}$ the court had to determine which way valuation should be carried out. Should it be carried out on the basis of what the creditor would receive under a foreclosure sale or should it be determined on the cost of replacement of comparable property? The Court ultimately decided by majority of eight to one that valuation should occur on a replacement basis.

The result of Rash mean that the value attributed to a secured motor vehicle is almost invariably less than the value of the debt owed to the creditor. This gave rise to the potential situation where the insolvent could incur debts knowingly prior to filing a plan and retain an asset without having to pay its full value. This occurred through an insolvent acquiring an asset that had a substantial depreciation component. The value of the security was often less than the value of the debt. Therefore under a Chapter 13 plan the secured portion of the debt was only ascribed the depreciated security value whilst the remainder of the debt was treated as unsecured. This unsecured portion often was completely lost to the creditor on discharge of the insolvent from the plan. Motor vehicles with their high rate of depreciation were an asset that often fell into this category.

The legislature under the Bankruptcy Abuse Prevention and Consumer Protection Act of 2005 (BAPCPA) combated this potential for abuse with the addition of what is known as the hanging paragraph. Abuse could take many forms but included the idea that debtors were incurring debts and were deliberately not honouring them and seeking refuge under what could be viewed as soft insolvency rules.

The hanging paragraph is so called because it has no numerical reference within the code it just sits there. It also does not relate to any of the points made in the previously numbered section. The "hanging paragraph" states ${ }^{150}$ :

For purposes of paragraph (5), section 506 shall not apply to a claim described in that paragraph if the creditor has a purchase money security interest securing the debt that is the subject of the claim, the debt was incurred within the 910-day period preceding the date of the filing of the petition, and the collateral for that debt consists of a motor vehicle (as defined in section 30102 of title 49) acquired for the personal use of the debtor, or if collateral for that debt consists of any other thing of value, if the debt was incurred during the 1-year period preceding that filing.

\footnotetext{
${ }^{149}$ Associates Commercial Corp v. Rash 520 U.U. 953 (1997).

${ }^{150} 11$ U.S.C. $\S 1325(\mathrm{a})$.
} 
The addition of this "hanging paragraph" is very significant for Chapter 13, as all secured debts have to be accounted for and paid in full unless there is cram-down. The key questions that this then gives rise to relate specifically to whether the "hanging paragraph" applies or not. The wording of the paragraph itself is express as to the timeframes when the obligation was entered into. It is further express about the fact the vehicle has to be for personal use and that the debt has to be a purchase money security interest (PMSI). But what is a PMSI and how is it defined? Collins ${ }^{151}$ indicates that the vast majority of Courts have held that a PMSI should draw its meaning from U.C.C. $\S 9-103^{152}$. The application of the definition by way of Collins example is straightforward: ${ }^{153}$

[A] seller of goods retaining an interest in those goods to secure the payment of all or some of the price of those goods. Third-party lenders can also retain a PMSI in a consumer good. This occurs when they make advances or incur obligations "to enable the debtor to acquire rights in or the use of the collateral" where those advances or obligations are "in fact so used" to acquire rights in that collateral.

In situations the application of the PMSI classification results in a negative, where the security held is worth less than the debt owed for it. If a negative equity situation occurs it must be determined whether the negative equity formed part of the "purchase price" or if the negative equity "enabled the debtor to acquire rights" 154 . The issues run deeper in that the question of the classification of this negative equity has not been resolved with any clarity by the courts. The current level of discourse on this provides a lack of certainty for both insolvents and creditors, with both parties facing significant litigation expense to answer this question. There exists considerable material on this debate which falls outside the scope of this paper. The key point is that there is no clear direction from the Court how a PMSI should be treated where negative equity exists.

The treatment of secured creditors under Chapter 13 plans is unique and different. Chapter 13 provides considerable benefit to the homeowner and allows

\footnotetext{
${ }^{151}$ Geoffrey M Collins "Negative Equity and Purchase Money Security Interests Under the Uniform Commercial Code and BAPCA" (2009) 95 Cornell L. Rev. 161 at 163.

${ }^{152}$ Uniform Commercial Code section 9-103.

${ }^{153}$ Collins, above $\mathrm{n} 151$ at 163.

${ }^{154}$ Uniform Commercial Code section 9-103(a)(2).
} 
many situations where the family home can be saved through the use of Chapter 13 . The "cram down" aspect of the Chapter 13 has been undermined by the "hanging paragraph" especially in cases relating to motor vehicles. Chapter 13 however still maintains a level of potency despite the uncertainties created by the "hanging paragraph".

\section{G Stakeholders and Chapter 13}

Chapter 13 provides a number of protections for all stakeholders to the insolvency. It firstly contains a codified process which all parties have the opportunity to access to understand their respective rights and obligations. Creditors of all classes have the opportunity to examine the insolvent under oath about the plan and the background to the insolvency ${ }^{155}$. Creditors also have the right to have their objections heard by the Court. The creditors are given 28 days' notice of the Court fixture so have ample opportunity to object ${ }^{156}$. Priority creditors still retain their preferential status, secured creditors retain their security and a minimum level of repayment based on the security they hold and unsecured creditors are guaranteed a greater return then they would enjoy under a Chapter 7 bankruptcy.

Insolvents are given immediate relief from creditor action on filing the petition; they are also obligated to commence payments within 30 days of filing. The insolvent is subjected to the scrutiny of the Court, trustee and creditors. Insolvents are incentivised to make a Chapter 13 plan work by being able to retain their assets thereby creating a level of certainty for creditors. There are also clear consequences when an insolvent is forced to convert to a Chapter 7 bankruptcy.

The trustee is independent of the insolvent and is there for compliance purposes. The trustee administers the plan and collects and distributes the funds as required. This creates a distance between the insolvent from the vitriol of creditors thereby reducing the stress on the insolvent.

\section{H Conclusions on Chapter 13}

Chapter 13 provides a mechanism for dealing with insolvency as a real alternative to liquidation bankruptcy. Whilst the system may not be perfect and is often criticised as favouring insolvents, it does provide an alternative that is viable.

\footnotetext{
15511 U.S.C. $\$ 343$.

${ }^{156}$ Federal Rules of Bankruptcy Procedure 2002(b).
} 
Unique features such as the cram down of secured creditors provides for an option that allows insolvents the ability to retain major assets. The system rewards insolvents whilst also providing creditors with more than they would otherwise enjoy.

A version of Chapter13 is a real alternative that could be imported to a jurisdiction like New Zealand. New Zealand would of course have the benefit of 30 odd years of US experience so could refine the wording to avoid some of the contradictions contained in the existing wording of Chapter 13. It is through this process of refinement that this paper will develop a New Zealand model for personal administration.

\section{Gateways}

\section{A Introduction}

Gateways are an important legal tool used by the legislature to control entry into or exit from various schemes and programs as sanctioned by the state. A gateway has a literal meaning in that it is something that has to be passed through before entering into the next section of whatever the gateway is controlling. In insolvency law gateways are common tools used to control entry into and exit from bankruptcy. A good example of a gateway is the credit counselling requirement before an individual can enter into a Chapter 13 Bankruptcy. ${ }^{157}$

Gateways are used as tools for a variety of differing reasons. This chapter is going to look at the various types of gateways and how they are being used in a variety of different jurisdictions. The public policy of gateway use is also tied into the various interests of stakeholders. This chapter will introduce a number of new jurisdictions. However the focus of the discussion of those jurisdictions will be limited to gateways and the evolution of those systems.

The purpose for this thesis to study gateways is to establish if a gateway or a series of gateways are going to assist the proposed amendments to the New Zealand insolvency regime. If a gateway could be identified that aided in the efficient administration of insolvencies then it would clearly benefit the proposed model.

\section{B Types of Gateways}

For the purpose of categorising gateways this section has broken them into three distinct types as follows:

${ }^{157} 11$ U.S.C. $\$ \S 109,111$. 
The restrictive gateway - designed to limit access to a bankruptcy regime. Such restrictive gateways involve steps that the insolvent has to complete or comply with in order to enter the scheme. Whilst some of these gateways are not onerous in their own right, the cumulative effect of them can make access to bankruptcy regimes a real barrier. An example of a restrictive gateway is the requirement for an individual to undergo credit counselling prior to entering into a Chapter 13 bankruptcy.

The Shepherding Gateway - has the purpose of sending people down a specific path with their bankruptcy. This type of gateway places certain criteria on entry into one scheme which if not complied with forces the individual into another scheme. This could be the division from a Chapter 13 to a Chapter 7 Bankruptcy in the US system, or it could be the different length of time in a Chapter 13 Bankruptcy based on the bankrupt's income.

The restrictive exit - is a far more subtle feature of bankruptcy regimes. There is a relatively universal approach to allowing a clean slate on exit from bankruptcy. However there exist a number of tools that the state or the trustee of the bankrupt estate can use to extend the bankruptcy period, thereby preventing or at least delaying the clean slate benefits that the bankrupt would enjoy on discharge. Some of these restrictions on discharge relate to the conduct of the individual during their bankruptcy while others can be used as punitive measures to punish conduct that led to the bankruptcy. In New Zealand a good example of a restrictive exit is a situation where the court grants a discharge but restricts the business activities that the discharged bankrupt can engage in. ${ }^{158}$

As the various jurisdictions are discussed during this section the various types of gateways included in those systems will be examined along with the cultural norms of each jurisdiction.

\section{Gateways in Practice - Continental Europe}

Continental Europe is made up of a variety of different jurisdictions and a variety of different cultural backgrounds. Detailed analysis of these markets is challenging for this author because of the language barriers associated with the secondary materials from these differing jurisdictions. Instead the focus of this thesis will be to highlight the key features of each system and any recent developments therein.

${ }^{158}$ Insolvency Act 2006, s 299. 
The French systems for dealing with personal bankruptcy have grown and developed rapidly over the last twenty years and are now one of the most efficient at dealing with personal bankruptcy. This efficiency has been created through a streamlined process that places a substantial amount of power with the regional commissioner under the commission on an individual over indebtedness which is administered principally by the Banque de France. ${ }^{159}$

Historically the first (but now out dated) tool used to curb overindebtedness was that the commission would work with the insolvent to develop a plan for the insolvent's affairs. This plan usually required concessions from creditors such as interest write offs, interest concessions, extensions on payment time frames and other forms of relief. The commission had the power to recommend these plans to the Court for enforcement if creditors did not voluntarily accept them. This system had one major weakness in that many insolvents, despite the relief offered, were still unable to break from their overindebtedness. As such they would often find themselves back before the commission trying to develop a more robust set of concessions. This system created many recidivist users who would continually be back before the commission without being able to resolve the underlying debt burden and its lack of sustainability.

The first major reform of this system introduced a compelled discharge as a form of relief. Beginning in 1999, the commissions could recommend the "extraordinary" measure of a global deferral of all debts for three years (in 2004, reduced to two years). After this period, if the commission's repeat evaluation revealed that the debtor was still unable to resolve a situation of financial distress using traditional "ordinary" measures of payment extensions, etc. The commission could recommend that the court impose a partial or total discharge of the unmanageable debt burden. ${ }^{160}$

The French then further fine-tuned the system in 2004 with the added ability of the commission to discharge insolvents of all of their debts, if the insolvent had all of their non-exempt assets liquidated. This process could only be instigated if the insolvent was in an "irremediably compromised" 161 financial situation. This process was called "procedure of personal recovery", Kilborn notes that this program

\footnotetext{
${ }^{159}$ Jason Kilborn, "La Responsabilisation de l'Economie: What the United States Can Learn From the New French Law on Consumer Overindebtedness” (2005) 26 Mich. J. Int'l L 619 at 637.

${ }^{160}$ Jason Kilborn, "Still Chasing Chimeras But Finally Slaying Some Dragons In the Quest for Consumer Bankruptcy Reform” (2012) 25 Loy. Consumer L. Rev 1 at26.

${ }^{161}$ At 26
} 
"resembles quite closely a U.S. Chapter 7 consumer bankruptcy"162 with no rehabilitation plan.

In 2010 the French system became even more efficient. The previous requirement for the court to approve composition plans as developed by the commission with the insolvent was dropped. Instead the commission had the power to impose the plans on creditors without the courts approval. This automatically freed up a considerable amount of court time. Creditors who were unhappy with the commission for imposing such a compromise measure on them did have a right of appeal to the court. ${ }^{163}$

The 2010 reforms also further streamlined the "procedure of personal recovery". The process of providing the court with inventories of assets that were non-exempt in liquidation was dispensed with. Instead the commission was granted the power to assess these cases and make an immediate recommendation to the court for discharge, which the court merely confirms as long as there is no creditor objection. This approach to dealing with such insolvents appears to be entirely practical as the vast majority of insolvents have no assets or the cost of administering their insolvency would outweigh the value of any assets that they do have.

The French have over the last twenty years removed most of the gateways within their insolvency regime. The current French systems focus on the commission as being the main gateway. The commission can shepherd insolvents down a variety of routes with the court being kept free for the purpose of confirming the commission's findings rather than developing its own.

\section{$2 \quad$ Sweden}

Historically the Swedish had a three step process, with all of the steps being a compulsory component prior to any form of relief being offered. There appears, from the literature, to be a general concern across Scandinavian culture of potential abuse of any insolvency regime that offers any form of discharge. ${ }^{164}$ Therefore the three step process was developed. These steps were as follows:

1. There was a compulsion for insolvents to try to reach a compromise with creditors. These negotiations were supported by budgetary advisors.

\footnotetext{
162 At 26.

163 At 26.

164 Jason Kilborn, "Out with the New, In with the Old: As Sweden Aggressively Streamlines Its Consumer Bankruptcy System, Have U.S. Reformers Fallen Off the Learning Curve?” (2007) 80 Am. Bankr. L.J. 435.
} 
2. Insolvents would then file with the state Enforcement Agency (Kronofogdigheten). The Enforcement Agency had the role of approving insolvents into the scheme. Insolvents who had incurred their debts through "irresponsible" choices such as substantial fines or consumption of luxury items were often deemed not suitable for relief. For those insolvents that were accepted the Enforcement Agency assisted with the development of a financial plan or composition for relief. This composition was then placed before creditors for their vote, which was usually in the negative.

3. The Enforcement Agency then took the plan to court for judicial review. This step almost always resulted in the court approving the plan and imposing it on creditors.

The Swedish reforms of 2007 brought in a revolutionary new approach. Firstly the Swedish system departed from the long held view that reaching a negotiated solution was an important first step. Instead the legislature recognised that in most situations creditors were unwilling to release insolvents from their respective obligations unless they had no other alternative. ${ }^{165}$ The second aspect of the reforms were just as practical and potent. The previous third step where the court had to review and the Enforcement Agency's composition was removed. The process was streamlined so that the Enforcement Agency would develop the composition which was then automatically approved by the court.

The Swedish system does not open any floodgates to discharge but instead provides access to a practical mechanism for financial relief that was previously missing. The major gateway now in the Swedish system is that of the Enforcement Agency as it now both develops the debt relief plan and sanctions it for court approval. This system does give considerable power to the gate keeper.

\section{Denmark}

Denmark in many respects has very similar cultural norms to Sweden regarding the perceived risk of abuse within any insolvency regime. The Danish reforms of 2005 in many ways blazed the trail for the Swedish reforms of 2007.

The paranoia over potential abuse has led to a system that is in many ways very narrow and targeted and only allows in a very select group of insolvents: Kilborn notes: ${ }^{166}$

\footnotetext{
${ }^{165}$ At 458.

${ }^{166}$ Kilborn, above n160 at 18.
} 
[D]ebtors must exhibit "qualified insolvency", which implies a complete impossibility, free from virtually any doubt, that debtors might right their own financial ships in the foreseeable future by reducing their living standards and applying their best efforts to paying off debt. Second, the court has to be convinced that the offering relief in any particular case is appropriate in light of a series of factors, such as the debtor's efforts to manage debt problems and the composition of the debt load (preferably relatively few fines, penalties, and "irresponsible" debts, such as debts for luxury consumption).

The key component of the 2005 Danish reforms was to change the presumption of the court. Pre 2005 the court had to look at all of the circumstances to see if the insolvent applicant was suitable for relief with the presumption that they were not. The reforms changed that presumption so that there was a presumption that the insolvent was suitable for relief unless demonstrated to the court otherwise.

The gateway for the Danish system is the court. It is the court that determines the suitability of the applicant for entry into the insolvency regime.

\section{$4 \quad$ Germany}

The only aspect of the German insolvency regime noted in this section is that of the cost of administration. The German system for dealing with insolvency essentially contained a user pays component. In order to enter into the regime the insolvent had to have the ability to pay for the costs of the administration of their insolvent estate. This obviously was a substantial hurdle for most insolvents to deal with. The German insolvency regime was updated in 2001 to allow the cost of the administration to be added to the insolvent's debts, thereby removing the cost barrier to entry into the scheme. The result of this update was a dramatic increase in the number of filings under the regime. ${ }^{167}$

The removal of the upfront administration burden opened the gateway significantly to insolvents wanting to avail themselves of the scheme.

\section{D $\quad$ United States of America}

Chapter 13 has already been discussed in a level of detail. That detail was focused on the mechanics of the regime and not on gateways. The gateway aspect of Chapter 13 will now be discussed.

\footnotetext{
${ }^{167}$ Jason Kilborn, “The Innovative German Approach to Consumer Debt Relief: Revolutionary Changes in German Law, and Surprising Lessons for the United States" (2004) 24 Nw. J. Int'l L. \& Bus. 257.
} 
The various entry criteria for Chapter 13 are as follows:

1. It is for individuals only; corporations are dealt with under other Chapters of the Code; and

2. The individual has to be a wage earner. Being self-employed is acceptable, and:

3. Secured debts must be less than $\$ 1,081,400$, and;

4. Unsecured debts have to be less than $\$ 360,0475$; and

5. The insolvent must not have been in default of any other creditor or debtor initiated bankruptcy proceedings in the proceeding 180 days, and

6. Have attended counselling from an approved credit counselling agency.

In reviewing the above it is clear that many gateways exist that restrict entry into the Chapter 13 program and failure of an insolvent on any one of the grounds bars them from inclusion in the scheme. Those insolvents who do not fit the criteria of Chapter 13 may seek relief in the form of Chapter 7, which is a liquidation bankruptcy, if of course the insolvent meets the criteria of entry to that particular scheme.

\section{E Australia and New Zealand}

Australia and New Zealand have a number of free trade agreements such as Closer Economic Relations and a general unwritten understanding of the mutual benefits of similar policy in commercial areas of law. When New Zealand revised its corporate insolvency regime to incorporate a voluntary administration model it used the Australian legislation as a template. It is therefore not surprising that the two jurisdictions have many similarities in their personal insolvency regimes.

Both Australia and New Zealand allow insolvents and creditors to work through their issues and create their own private or informal solutions. Whilst these informal solutions are encouraged they are not prerequisites for entry into any of the personal insolvency options available in each respective jurisdiction. Both jurisdictions also offer alternatives to bankruptcy through recognised state sanctioned programs. Examples in New Zealand are the No Asset Procedure, Summary Instalment Orders, or Proposals under Part 5 of the Insolvency Act 2006. In Australia there are formal Debt Agreements and Personal Insolvency Agreements.

Whilst none of these alternatives to bankruptcy are gateways to bankruptcy they do offering a filtering system where some insolvents are able to be shepherded off down different paths rather than bankruptcy. Australia also has a suspension 
program that creates a moratorium on creditor action for a short period of time to all insolvents to consider their various alternatives (some creditors like secured creditors are not stopped from continuing enforcement action under this provision). This moratorium is also not a gateway but rather a holding pen before further action is taken.

Bankruptcy in both Australia and New Zealand is entered into either by the insolvent petitioning the local Insolvency Trustee or a creditor making an application to the court. Both entry mechanisms are gateways and each have criteria that the court or the trustee will consider prior to bankruptcy being entered into.

Interestingly both jurisdictions have a three year bankruptcy, with the time starting for the measurement of the three years being when the trustee receives a completed statement of affairs. Discharge in both jurisdictions is with a clean slate apart from a few minor obligations such as Child Support payments (in New Zealand $)^{168}$. Discharge can also be withheld in both countries by the trustee making an application to the court.

Australia and New Zealand's' discharge provisions did diverge for a period of about a decade from 1991 to 2002. Australia over this period had an early discharge program for bankruptcy. The length of three years is of course completely arbitrary and has no scientific basis. Senator Gareth Evans asked the Australian Attorney General in 1980: ${ }^{169}$

[W] hat principle, if any, has in fact guided the determination and settling upon the period of three years. It is just the time honoured principle that any longer than that would be too long, and any shorter would be too short? In other words, does it have an intuitive quality about it, or is there something more rational?

The recorded response to this line of questioning was a nod from the Attorney General. This in my view can be taken as acceptance by the legislature that the length of bankruptcy prior to discharge serves no purpose other than being punitive on the bankrupt. Whilst there needs to be an adequate timeframe for the trustee to examine the affairs of the bankrupt this could conceivably be done within a shorter timeframe. For the purposes of a discussion on gateways it should be noted that discharge from bankruptcy is also a gateway. Regardless of the time spent in bankruptcy as dictated by the state at some point the bankrupt has to be discharged. This gateway has two components to it in both Australia and New Zealand. Firstly the three year time frame has to have elapsed. Secondly the trustee must consent to the release. The legislation

\footnotetext{
${ }^{168}$ Insolvency Act 2006, s 304.

${ }^{169}$ Commonwealth of Australia, Parliamentary Debates, Senate, 25 March 1980, 999 (Gareth Evans).
} 
in both jurisdictions creates a presumption that the trustee has agreed (tacitly) if the trustee has not filed an objection with the court. If such an objection has been filed it is up to the court to determine whether discharge should occur or be delayed.

\section{F Trends in Gateways}

There is a clear move in the jurisdictions of Continental Europe as discussed above that access to insolvency regimes should be made easier. This shift is despite the cultural norms of those various jurisdictions and the concerns about potential abuse. Gateways are as a general rule being opened to allow greater numbers of insolvents access to financial relief. This pattern appears to have been steady and consistent across these jurisdictions over the last couple of decades.

The United States were the world leader in insolvency and bankruptcy legislation, having recognised the issues and had state sanctioned relief with ease of access since the nineteen seventies through the Bankruptcy Code. However the consumer bankruptcy reforms of 2005 resulted in a stark policy change in direction. Titled the "Bankruptcy Abuse Prevention and Consumer Protection Act" or BAPCPA the new legislation started to place considerable restrictions on what was previously an extremely liberal scheme.

BAPCPA created two new hurdles to entering into a bankruptcy regime under the code. Firstly the requirement for credit counselling was added as an additional gateway entry criteria. Secondly the addition of a means test as a way of discovering potential abuse of the bankruptcy regime acts as a shepherding gateway depending on the two step testing process. The means test was designed to prevent immediate discharge from bankruptcy for Chapter 7 filers, if they had the ability to pay a dividend.

Those insolvents who pass the means test are allowed to continue with a Chapter7 bankruptcy with immediate discharge. Those that fail the two step means test, (which contains a range of formulae based on the insolvents pre filing income and also their income verses state averages for the equivalent sized family minus presumed expenses). If the means test is failed the bankruptcy is converted to a Chapter 13 bankruptcy where the insolvent is required to make payments from their income over a five year period, regardless of whether they have any assets or not. 
The developments under BAPCPA appear to create both entry and discharge gateways that did not exist prior to this legislation. Kilborn, a vocal academic critic of these reforms, comments on the background to these reforms as follows: ${ }^{170}$

Three factors converged to push an ill-conceived and poorly drafted reform bill through the legislative process: (1) the ebb and flow of politics had moved toward a more conservative position, (2) the general economic situation (especially investment asset values, such as home equity and stocks) was at all-time highs, and yet (3) annual personal bankruptcy filings had exceeded the psychologically important one million mark in 1996.

It was against this backdrop that a major credit card issuing bank (MBNA) drafted the reform bill that lead to the BAPCPA legislation. The motivation of the legislation appears to be that insolvents with capacity/ability to pay were made to do so. The onerous and cumbersome nature of the legislation caused it to instead create inefficiencies and court congestion due in large part to its poor drafting. ${ }^{171}$ The additional cost and increased compliance is borne by all insolvents even though the vast majority pass the means test and enjoy the benefits of immediate discharge.

In Australia and New Zealand personal insolvency legislation has remained largely unchanged for decades, apart from the limited addition of some alternatives to bankruptcy and the removal of early discharge in Australia. The legislation and processes associated with bankruptcy in both jurisdictions remains almost the same since the late nineteen sixties. This is despite new legislation being enacted (which covered the alternatives to bankruptcy but made little reform to bankruptcy itself).

As such the Australasian model has had no real development in respect to gateways apart from the shepherding options prior to bankruptcy. However it should be noted that New Zealand and Australia have both seen a broadening in corporate insolvency alternatives over this same time frame, with both jurisdictions containing voluntary administration options for corporate insolvents.

The summation of international trends still appears to be strongly towards a liberalisation of insolvency regimes. This liberalisation is being achieved through the removal of barriers to entry into such schemes with the widening of gateways. While the US Bankruptcy Code has bucked the trend it still does provide a mechanism for relief notwithstanding the additional gateway requirements.

\footnotetext{
${ }^{170}$ Kilborn, above n 160 at 3.

171 At 3.
} 
Gateways provide an interesting benefit to all stakeholders. It is at a gateway where all of the interests of all stakeholders collide. By restricting entry to or discharge from a bankruptcy or an insolvency alternative by use of a gateway the interests of all parties get to be aired. Further shepherding insolvency cases down different paths based on some general fact criteria does create the potential for creditors to benefit from a dividend even if it is only a small one.

The balancing act for the legislature has to be between the prevention of abuse and the easy flow of an efficient system. Too many cumbersome requirements add compliance costs on all parties and limits access to financial relief. Too few restrictions open the system up to abuse or the perception of abuse amongst competing stakeholders. The correct solution to these competing interests will vary from state to state depending on the cultural norms and expectations of each state.

\section{H Conclusion}

Gateways exist as common place across all jurisdictions in relation to insolvency and bankruptcy regimes. In some cases gateways are overt and in others they are more subtle. The key point is that gateways allow and control the flow of insolvency and bankruptcy cases through their respective jurisdictions. More efficient regimes offer less gateways with gate keepers that conform to the trust and cultural norms of the jurisdiction in question. Less efficient regimes add layers of bureaucracy and compliance criteria onto the regime in the hope of preventing abuse, which occurs only in the minority of circumstances. Ultimately if the gate keeper is trusted the regime is trusted.

For the purposes of recommending reform the open gateways of Continental Europe have considerable appeal. Allowing easy access and diverting procedural processes away from the courts these gateways appear to be making insolvency relief more accessible. The freedom of flow in these jurisdictions does not appear to be opening a floodgate of abuse. 


\section{Insolvency Solutions for New Zealand}

\section{A Introduction}

Over the proceeding chapters the current New Zealand system and those of other western jurisdictions have been examined. The overall summary of all the studied material is that that there exists a wide variety of ways of dealing with personal and consumer insolvency and bankruptcy. It is this variety that creates efficiencies or inefficiencies all within the one jurisdiction. The key point to be drawn from this is that each insolvency situation is unique and therefore a variety of mechanisms for managing them lubricates the overall insolvency system.

It is clearly completely impractical to have an unlimited number of alternatives within an insolvency regime. However a small number of flexible alternatives does appear to be the best form for an insolvency regime to take.

The current alternatives to bankruptcy of the No Asset Procedure and the Summary Instalment Order have a place within these proposed reforms. The benefit of these alternatives in the current system will be demonstrated through the statistical uptake of these insolvency options.

Insolvency has an enormous effect on the insolvent and their creditors. Therefore decisions relating to which insolvency alternative should be utilised should not be rushed into. Nor should an insolvent be driven to bankruptcy if there are viable alternatives. Therefore the first of the proposed amendments to the Insolvency Act is to adopt a holding system whereby an insolvent can call a brief timeout so as to assess their alternatives. This brief reprieve will be based on the Australian model. Critics will argue that such a system will be only delaying the inevitable however it fills an important gap that exists in the current system.

One of the major focuses of this thesis is the development of a single assessment gateway for insolvents. On entering through the gateway individuals will become personally insolvent. From there they will be assessed by the Official Assignee before proceeding down one of the prescribed alternatives. The key component of this is an assessment on the filing of a statement of affairs (debtor petition) or on the court's referral (creditor petition). This gateway step will become a compulsory precursor to bankruptcy. All insolvents under this system will be required to file with the Trustee a complete statement of affairs prior to any further action occurring. If the information provided raises further questions for the trustee an 
investigation can be undertaken by the trustee before proceeding to one of the three proposed outcomes.

The first proposed outcome is the second major focus of this thesis, being personal administration. This would be an alternative to bankruptcy that would require a level of creditor approval. The general aim of this alternative is to allow the insolvent to contribute other assets or income streams into their insolvency that would not otherwise be available to creditors, thereby giving the creditors a better return and incentivising the insolvent to optimise their productivity as they stand to be better off if they do.

For insolvents who are unable or unwilling to proceed with a personal administration program bankruptcy is still an alternative. It is proposed there be two bankruptcy options, with both being liquidated bankruptcies meaning that all the insolvent's assets are realised by the trustee for the benefit of creditors. The first bankruptcy option allows for immediate discharge. This option would be only available to first time bankrupts and would only be used in situations where the cost of administration would outweigh any potential dividend. The second form of liquidated bankruptcy would be along the lines of the current traditional bankruptcy model and would last for three years. Both of these liquidated bankruptcy alternatives will be discussed in more detail.

The need for there to be further amendments to the New Zealand insolvency regime are argued as being a direct result of the 2006 reforms not proceeding as far as the Ministry of Economic Development recommendations. ${ }^{172}$ Those recommendations included many ideas and concepts that have been developed in this chapter. Concepts such as suspension of proceedings, debtor and creditor education, incentives for early intervention and early discharge all form the basis of the proposed amendments.

\section{B Suspension of Proceedings}

As a generalisation one of the biggest issues with insolvents is denial or at least a lack by the insolvent being proactive in trying to reach an alternative to bankruptcy. This may be because they feel bankruptcy is inevitable. Or it could be that they do not realize alternatives exist that may be able to resolve their situation. Where creditors have exercised their legal rights to enforce a debt or obligation then the insolvent is also under time pressure as well as the financial pressure. Under such

\footnotetext{
${ }^{172}$ Ministry of Economic Development Insolvency Law Review: Tier One Discussion Documents (Ministry of Economic Development, Wellington, 2001).
} 
emotional strain it is possible for insolvents to lack the clarity of vision required to fully assess their options.

By its very nature a suspension of proceedings, under the proposed amendment, can only occur if a creditor has issued proceedings in Court. As a general proposition it will be assumed that most insolvents do not have a clear understanding of the processes surrounding insolvency and bankruptcy. The Court should therefore be obliged to offer the suspension of proceedings to all insolvents that appear before the Court. The merits of the bankruptcy notice ${ }^{173}$ or other court proceedings are irrelevant. The debtor has the option of suspension provided they agree to attend a meeting with the trustee. The purpose of this meeting is to provide advice on the alternatives for the insolvent. There would be strict timeframes involved with any suspension of proceedings, as per the Australian model the suspension could last for a maximum of 21 days. Once the insolvent had received advice and the suspension had expired they would return to Court for the matter to resume.

As in the Australian model this suspension is not designed to circumvent the contractual rights of secured lenders from exercising their right to enforce their securities. This suspension should be distinguished from the asset freezes offered under the US Bankruptcy Code. Instead this suspension is designed to provide the insolvent with education, advice and thinking space so they are aware of their options prior to formally entering into an insolvency procedure. There is potential for an insolvent to dispose of assets over this period which could lead to creditors being deprived of an asset that would otherwise form part of the insolvent's estate. This exact scenario was discussed at length at the Creditor's Remedies Conference of 2001. At this point the discussion related to moving the effective start date of bankruptcy from the "act of bankruptcy" to the point of adjudication. It was eventually decided that the rules associated with voidable transactions were strong enough to provide adequate creditor protection. ${ }^{174}$ While this situation cannot be directly controlled if an insolvent choses to act in a dishonest manner it can be tempered by the use of the voidable transactions provisions already contained in the legislation ${ }^{175}$. In order to add further protection to creditors, when a suspension is granted the Court would also make the insolvent aware that if they tried to use the extension to dispose of assets they would be deemed to have acted in bad faith and would not be eligible for immediate discharge as discussed below. With these creditor protections in place the position of all stakeholders is relatively protected. There are

\footnotetext{
${ }^{173}$ Insolvency Act 2006, ss $16-29$.

${ }^{174}$ Fleur Baker and Ralph Simpson Creditors' Remedies (Continuing Education Department of the New Zealand Law Society July 2001) 145.

${ }^{175}$ Insolvency Act 2006, section 194-216, covering insolvent transactions, insolvent charges, insolvent gifts, irregular transactions, under value transactions and contributions to other people's property.
} 
some unique situations where stakeholders cannot be protected with a suspension, these are situations where the insolvent's estate consists of items that are perishable and the suspension causes a delay which would see such items expire. Overall however a suspension facility provides for a protected environment which allows better decisions to be made by insolvents without compromising the stakeholder's positions.

Whilst the office of the Official Assignee currently is more than happy to meet with individuals who are facing financial troubles, very few people avail themselves of this option. At present an insolvent who is facing creditor petition in court can request a delay in proceedings, which is granted at the discretion of the Court. While this can allow the insolvent more time, there is no compulsion on them to seek further advice, education or explore alternatives. It is suggested that by encouraging a meeting early in court proceedings efficiencies will be created further in the system.

\section{Alternatives to Bankruptcy}

New Zealand's existing alternatives to bankruptcy fit a range of special situations that provide all parties a range of options. There are situations where the size and nature of the debt is relatively small but the ability to repay as per the contracted terms is nevertheless not possible, or there are situations where creditors are in agreement with a proposal presented by an insolvent. In these situations it makes sense that any amendments to the New Zealand legislation continue to incorporate these existing features. As such the existing systems of Part 5 Proposals ${ }^{176}$, Summary Instalment Orders ${ }^{177}$ and No Asset Procedures ${ }^{178}$ would all be maintained in any new model. It is conceded that there will be some overlap between these existing options and the proposed amendments.

When the Ministry of Economic Development made recommendations for reform of the 1967 Insolvency Act ${ }^{179}$ it suggested that bankrupts who were not guilty of any misconduct should be discharged after one year. It was from this broad recommendation that the No Asset Procedure system was developed. Essentially the No Asset Procedure is a mini bankruptcy which is administrated by the Official Assignee rather than the courts. It is limited by the level of debt that is allowable under the regime. Currently it requires the insolvent to owe between $\$ 1,000$ and $\$ 40,000$. If there was an alternative of a liquidated bankruptcy with immediate

\footnotetext{
${ }^{176}$ Insolvency Act 2006 s 326.

${ }^{177}$ Insolvency Act 2006 s340.

${ }^{178}$ Insolvency Act 2006 s361.

${ }^{179}$ Ministry of Economic Development, above n 172 at 47.
} 
discharge, that solution could compete directly with the No Asset Procedures where debt levels were in the same band.

It is suggested that an easy access option that does not require the gateway of personal insolvency (see below) provides a benefit. This coupled with the No Asset Procedure not incurring the same stigma as bankruptcy means that the two can coexist despite the overlap. Likewise Proposals and Summary Instalment Orders can exist in tandem with personal administration. The thrust of this thesis is to provide multiple options to insolvents when considering entering into an insolvency regime. More options should yield better outcomes for stakeholders, especially with the new oversight powers being granted to the office of the Official Assignee.

\section{The Gateway into Personal Insolvency}

The concept of gateways in insolvency procedures is not new as discussed in previous chapters. The issue with gateways is the balancing between having an entry criteria and managing flow without either limiting access to relief or opening up floodgates where abuse is a perceived issue. Jason Kilborn ${ }^{180}$ in his many works has raised considerable concern about using gateways to protect against perceived abuse of insolvency relief. The statistics that he relies on indicate that the vast majority of insolvencies across varying jurisdictions are void of debtor fraud. The underlying theme of his work is that systems which involve less restrictions and lubrication of process are the most efficient. This thesis supports the view of Kilborn, in that processes should be simple and access to relief should be straightforward. However there still needs to be a system that has integrity and can be relied upon by all stakeholders.

The first gateway proposed and discussed in this chapter is not a gateway to bankruptcy. Instead it is a gateway into an insolvency regime. For the purpose of this paper it will be referred to as the insolvency gateway. The regime which it controls access to shall, also for the purpose of this thesis, be referred to as personal insolvency. This chapter will outline a proposed method of personal insolvency and the options that can flow from it which are: traditional liquidated bankruptcy, a proposal for personal administration or liquidated bankruptcy with immediate discharge. Once personal insolvency has been entered into there is a second gateway that performs a shepherding function to which will be referred to as the shepherding gateway. The shepherding gateway shepherds insolvents to one of the three options mentioned above.

\footnotetext{
${ }^{180}$ Kilborn, above n 160.
} 


\section{E Proposed Wording of Statute for Entry into Personal Insolvency}

For debtor petition the current section 47 would be replaced with the following wording:

\section{Debtor automatically adjudicated personally insolvent}

(1) A debtor who files an application with the Assignee to have himself or herself adjudicated bankrupt is automatically adjudicated personally insolvent when the application is filed.

(2) That adjudication has the same consequences as if the debtor had been adjudicated personally insolvent by the court.

For creditor petition to the High Court the current section 55 would be replaced with the following wording:

\section{Personal Insolvency commences on adjudication}

Personal Insolvency commences on the date and at the time when a debtor fails to comply with a Bankruptcy Notice as contained in Section 17 of this Act.

The actual acts of bankruptcy referred to in section 17 would not change and would remain as being ${ }^{181}$ :

\section{Failure to comply with bankruptcy notice}

(1) A debtor commits an act of bankruptcy if-

(a) a creditor has obtained a final judgment or a final order against the debtor for any amount; and

(b) execution of the judgment or order has not been halted by a court; and

(c) the debtor has been served with a bankruptcy notice; and

(d) the debtor has not, within the time limit specified in subsection (4),-

(i) complied with the requirements of the notice; or

(ii) satisfied the court that he or she has a cross claim against the creditor.

(2) The form that the bankruptcy notice must take is set out in section 29.

(3) The debtor must have been served with the bankruptcy notice in New Zealand, unless the court gave permission for the service of the notice on the debtor outside New Zealand.

\footnotetext{
${ }^{181}$ Insolvency Act 2006, s 17.
} 
(4) The time limit referred to in subsection (1)(d) is,-

(a) if the debtor is served with the bankruptcy notice in New Zealand, 10 working days after service; or

(b) if the debtor is served outside New Zealand, the time specified in the order of the court permitting service outside New Zealand.

(5) In this section, a creditor who has obtained a final judgment or a final order includes a person who is for the time being entitled to enforce a final judgment or final order.

(6) In this section, if a court has given permission for enforcing an arbitration award that the debtor pay money to the creditor,-

(a) final order includes the arbitration award; and

(b) proceedings includes the arbitration proceedings in which the award was made.

(7) In subsection (1)(d)(ii), cross claim means a counterclaim, setoff, or cross demand that-

(a) is equal to, or greater than, the judgment debt or the amount that the debtor has been ordered to pay; and

(b) the debtor could not use as a defence in the action or proceedings in which the judgment or the order, as the case may be, was obtained.

Section 10 of the existing Act relating to adjudication would also have to be amended as bankruptcy could now only be entered into by order of the Official Assignee or the Court. Such an order could only be made after the insolvent had been in personal insolvency and the Official Assignee had examined them. This amendment does deny debtors from entering directly into bankruptcy through debtor petition. However this is offset against the argued benefit that personal insolvency and Official Assignee examination could result in a better form of relief than traditional bankruptcy.

\section{F $\quad$ Ease of Entry}

New Zealand has historically enjoyed an insolvency regime that is easy to enter. That feature must be retained in any reform. The 2006 Act and its 1967 predecessor both featured entry either by debtor petition or creditor petition. Where a debtor filed, there was and is no filing fee and no obligation to contribute to the cost of any administration of the bankrupt estate should there be no realisable assets. It is this ease of entry that must be retained through personal insolvency not requiring any fee for filing and no further fee being required for any of the alternatives of the shepherding gateway. The German Insolvenzordnung removed the upfront cost of administration with effect in 2002. This saw the number of filed insolvencies triple 
from 15,000 to about $45,000^{182}$ that year. It is therefore paramount to retain the no cost entry to the regime so that no barrier to entry exists.

Creditor petition is through the courts. The insolvent does not have to incur the direct cost of this procedure, unless they engage representation for the proceedings. The costs incurred by the petitioning creditor become a priority debt for the bankrupt estate. The downside of this system is that a practically unrecoverable cost burden is placed on a creditor. As such many creditors elect not to pursue debts to bankruptcy of the debtor because they stand to lose these legal fees as well.

It is therefore proposed that the gateway for creditor petition be moved from an adjudication by the court to the point where an act of bankruptcy has been committed by virtue of the expiry of a bankruptcy notice. By moving the gateway to this point the creditor is able to avoid the additional court costs of an appearance in court and achieve a result at a lower cost point. The insolvent is not disadvantaged, the bankruptcy notice has been filed in the court and the insolvent has been served ${ }^{183}$. The notice in its current format as defined in Form B2 ${ }^{184}$ clearly outlines the insolvent's options. If the insolvent does not comply with the options then on the expiry of the notice they will pass through the gateway. Under the current law the expiration of a bankruptcy notice equates to an act of bankruptcy. Once an individual has performed an act of bankruptcy under the current legislation the creditor can apply to the court for an adjudication.

The practical application of this amendment is explained by way of an example of a creditor pursuing a debtor to personal insolvency. A debtor who has failed to pay a judgement creditor and has also failed to lodge a valid counter claim could be served with a Bankruptcy Notice, in the same manner and prescribed format as exists under the current legislation. For the creditor to issue such a notice they incur a modest filing fee and the court processes the bankruptcy notice on the papers, with there being no need for a hearing. Once the debtor has been correctly served with the notice the creditor needs to take no further enforcement action. If the debtor fails to make payment as per the bankruptcy notice prior to that notice expiring or complying with any other requirement contained within that notice, then an act of bankruptcy has been performed. On performance of an act of bankruptcy the debtor would immediately pass into personal insolvency and their assets vested with the Official Assignee. The insolvent debtor now would have to file a statement of affairs with the

\footnotetext{
${ }^{182}$ Kilborn, above n 160 at 23.

${ }^{183}$ Insolvency Act 2006, s 17(4)(a).

${ }^{184}$ Insolvency Act 2006, Schedule 1.
} 
Official Assignee and have their affairs examined before an insolvency alternative could be decided upon.

Conversely if a debtor wanted to file their own application as per section 46 and the amended section 47 mentioned above they could do so. In completing a statement of affairs document and filing it with the office of the Official Assignee the individual would pass into personal insolvency and their affairs would be scrutinised by the Official Assignee. It is hoped as an incentive to encourage debtors to take action sooner that such an application, if it met the general criteria discussed below, could lead to immediate discharge. Under the current legislation an individual who files a debtor's petition is adjudicated bankrupt. By adding in the step of personal insolvency and its associated scrutiny from the Official Assignee it is intended that insolvents can be progressed through the system faster, especially in cases where immediate discharge or personal insolvency are alternatives.

This now creates a side issue. Historically there are a number of instances where bankruptcy notices have been found by the courts to be deficient. If the gateway is passed through at the expiration of the bankruptcy notice then there must be a system for checking the notice prior to its expiration. Current grounds where bankruptcy notices have been considered defective are identified by Street Legal as follows: $:^{185}$

1. Has the bankruptcy notice been served within 1 month of the date on which it was issued by the High Court? If the bankruptcy notice is renewed then it must be served within 1 month from the expiry of the initial period, or from the expiry of the last period of renewal and not from the date of the order of renewal.

2. Was the bankruptcy notice personally served in accordance with rules 6.1 and 6.8 of the High Court Rules, or was there an order for substituted service?

3. Does the bankruptcy notice state the amount of any costs claimed against you;

4. Does the bankruptcy notice include a full address for payment of the debt. In Re Matheson, ex parte Watson [1972] NZLR 1084 the address for payment specified in the notice was "Auckland". The Court considered that insufficient and the defect was not cured just because an address for service was contained in the bankruptcy notice.

5. Does the bankruptcy notice include the full name and address of the judgment creditor or the full name and address for service of the

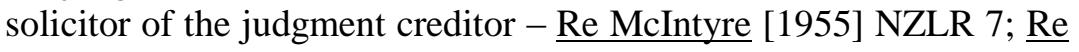
Trueman ex parte Western-Webb and Co [1959] NZLR 737.

6. Does the bankruptcy notice state all prescribed methods of satisfying the notice. A failure to include any of the contents of

${ }^{185}$ Street Legal, "Introduction to Bankruptcy Notices" < http://www.legalstreet.co.nz/bankruptcy.html>. 
paragraph 1 of the notice in Form B2 can make the notice defective. In Re Boddie, ex parte Amburys Ltd [1933] NZLR 1012 the words "or the satisfaction of the Court" were left out. The Court held that the bankruptcy notice was defective and dismissed the petition.

7. Does the bankruptcy notice purport to be issued in respect to more than one judgment - Re Low [1891] 1 QB 148; Carlyle v McCardle Richardson (HC, Wellington B 394/96, 12 March 1997, Master Thomson)

Despite the above, a Court may still order that a defective Bankruptcy Notice not be set aside pursuant to Section 418 of the Insolvency Act 2006. However this order may not be made if the debtor is prejudiced by the defect.

The issues surrounding the deficiencies in potential bankruptcy notices will create litigation regardless, whether they are the entry point to the insolvency regime or not. It is argued that any additional litigation created by moving the gateway to the expiry of such a notice is outweighed by the reduction in the Court's time in hearing bankruptcy applications and associated proceedings. If an insolvent is issued with a bankruptcy notice which they believe to be deficient they will retain their right of recourse to the court to have the validity of the notice ruled upon. The practical reality of such an examination of the notice if found deficient will only result in a new notice being issued which does not contain the deficiency. Such an argument may only result in achieving little more than a delay in the process.

By moving the gateway to personal insolvency to the point at which the bankruptcy notice expires, a new incentive is created for debtors who wish to file a proposal under Part 5 of the Insolvency Act to do so earlier. Situations like the one that arose in Henderson ${ }^{186}$ where the Court is hearing both a proposal and an application for adjudication would no longer occur. Instead if the bankruptcy notice had expired the Official Assignee would examine the insolvent and there would be no need for a hearing. The insolvent is therefore incentivised to place a proposal before the court well before a creditor takes steps to issue a bankruptcy notice.

It is important to note, that the option discussed earlier to suspend proceedings would now apply to suspending the bankruptcy notice for the prescribed timeframe. Such a suspension of the bankruptcy notice would require a brief amendment to the Insolvency Act 2006 s17. The point being that the insolvent is given the opportunity to engage with the Official Assignee and understand their options prior to the bankruptcy notice expiring. This means that the debtor who qualifies for one of the alternatives such as the No Asset Procedure can enter that program prior to the expiration of the bankruptcy notice.

\footnotetext{
${ }^{186}$ Henderson, ex parte Commissioner for Inland Revenue (2011) 25 NZTC 20-049.
} 
If a consumer debtor defaulted on their obligations and a bankruptcy notice was served on them, the debtor could apply for a suspension of the bankruptcy notice so they could learn more about their alternatives. The office of the Official Assignee would have a legislated monopoly on the provision of further information in these circumstances. This system creates consistency and reliability of information being provided to insolvents.

\section{G The Second Gateway}

The second gateway is the shepherding gateway and only applies to insolvents who are already in personal insolvency by virtue of having passed through the insolvency gateway by one of the two prescribed methods. Those methods being expiration of a bankruptcy notice and debtor petition. The outcomes for insolvents who present at the shepherding gateway will be heavily dictated by their statement of affairs and by what outcome the insolvent is wanting to achieve. If the insolvent does not wish to attempt financial rehabilitation through personal administration then only the two liquidated bankruptcy alternatives are available to them.

The statement of affairs is a prescribed form that all personal insolvents are required to complete whether they entered the program through debtor petition or the expiration of a bankruptcy notice. After the Official Assignee has examined the form they can determine if the insolvent should be granted an immediate discharge or whether they should remain undischarged for three years, or longer if court orders are sought. These alternative forms of bankruptcy and associated discharge procedures are further discussed later in the chapter. The important point to note is that there is a second gateway that determines the insolvency's administrative outcome.

\section{H Stakeholders}

The cost of creditor petition is reduced, the creditor only would have to pay for the issuing and service of a bankruptcy notice, rather than incurring the costs associated with a full hearing as is the current situation. Such amendments will make New Zealand's insolvency regime the most open and accessible for all parties. The costs for creditors of entry into personal insolvency by creditor petition have been reduced and a fair balance has been achieved. Debtors, if they wish can enter the 
scheme with no personal financial outlay. Under this proposed model creditors can now enjoy the same low cost access to the system. Further by truncating the process the insolvent's affairs are examined earlier than they may otherwise have been. This achieves the double benefit of offering the insolvent earlier relief and reducing the opportunity for the insolvent to create further indebtedness.

The insolvent also benefits from the ability to seek a suspension of proceedings so as to get advice and information which they may not have been aware of under the existing model. If the insolvent is informed about the alternatives it may result in them immediately filing for a debtor's petition rather than waiting for the expiration of a bankruptcy notice.

By bypassing the court to achieve a state of personal insolvency, stakeholders get direct access to the regime. This frees up the court to hear only substantive matters and technical arguments rather than the court being a processing centre. Regular applicants to the court such as the Commissioner for Inland Revenue save considerable time and expense in dealing with applications which are seldom defended. Those applicants that dispute the debt still have the right to make an application to the court to set aside the bankruptcy notice and will be successful if they have valid grounds for doing so.

The Official Assignee is a government official. The model of personal insolvency only works in a robust manner if the public and the courts have confidence in the office of the Official Assignee. The proposed amendment of utilising the office of the Official Assignee creates a potential risk for differing offices to implement the proposed changes differently. Such examples of a regional variation have been seen in other jurisdictions where a regional trustee is given considerable discretion under the legislation. ${ }^{187}$ In order to avoid such variance the right to appeal any regional decision to the court must be retained.

Although the process of personal administration differs from the current model, the function and role of the Official Assignee does not change. The Official Assignee is still responsible for the administration of the insolvent's estate, and all property of the insolvent vests with the Official Assignee. The Official Assignee still retains the right to investigate the insolvent's affairs and prosecute them if they find wrong doing. The only difference in the role of the Official Assignee relates to the first gateway where administration starts on the expiration of the bankruptcy notice rather than at adjudication.

\footnotetext{
${ }^{187}$ Jason Kilborn, “Twenty-Five Years of Consumer Bankruptcy in Continental Europe: Internalizing Negative Externalities and Humanizing Justice in Denmark” (2009) 18 Insol. Rev. 155 at 174.
} 
By having a single entry gateway to personal insolvency that can only be passed by two very distinct actions, debtor petition or expiration of a bankruptcy notice; creates certainty for the system. The proposed system of personal insolvency must be deemed to be efficient by the criteria set out by Kilborn ${ }^{188}$ in assessing European jurisdictions, in that there is no barrier to entry into the scheme, no upfront financial cost and no delay. Under personal insolvency creditors start to enjoy the same efficiencies as insolvents in enforcing their respective rights and access to relief.

\section{I $\quad$ Liquidated Bankruptcy with Discharge}

It is accepted that there are many aspects to liquidated bankruptcies. This thesis choses to only focus on discharge as a comparative reference to the suggested model of personal administration. By further examining discharge and providing discharge alternatives it is argued that the overall insolvency regime becomes more robust by having more viable alternatives.

Once an insolvent has entered into personal insolvency there can only be three different outcomes. These outcomes are a liquidated bankruptcy with immediate discharge, a liquidated bankruptcy with a traditional discharge (the current model) or personal administration. This section deals with liquidated bankruptcy and the two approaches to discharge. Penney notes: ${ }^{189}$

The discharge of bankrupts is a vital part of the bankruptcy regime. In exchange for giving up their assets, complying with the restrictions placed on them by the Insolvency Act and co-operating with the Official Assignee (OA) the bankrupt is released from those debts that formed the bankruptcy. Once freed from the burden of crippling debts the bankrupt can once again make a positive contribution to society.

Discharge represents the final stage of the bankruptcy process. It is where the bankrupt moves from being under the control of the Official Assignee with the restrictions placed on them by the Insolvency Act to a normal legal status. As this transition takes place the bankrupt ceases making any financial contributions to creditors that may have been ordered. They are also free to avail themselves of credit facilities if they so wish.

\footnotetext{
${ }^{188}$ Kilborn, above n 160 at 1.

${ }^{189}$ Penney, above n 27 at 1 ..
} 
Most of the activity surrounding bankruptcy occurs on entry into the regime. This is where the bankrupt is assigned a new IRD number and their debts are moved to their bankrupt estate. On discharge bankrupts cease to be liable for their debts and the clean slate is given subject to a few criteria as set out in section 304 which states: ${ }^{190}$

\section{Debts from which bankrupt is released on discharge}

(1) On discharge, the bankrupt is released from all debts provable in the bankruptcy except those listed in subsection (2).

(2) The bankrupt is not released from the following debts:

(a) any debt or liability incurred by fraud or fraudulent breach of trust to which the bankrupt was a party:

(b) any debt or liability for which the bankrupt has obtained forbearance through fraud to which the bankrupt was a party:

(c) any judgment debt or amount payable under any order for which the bankrupt is liable under section 147 or section 298:

(d) any amount payable under a maintenance order under the Family Proceedings Act 1980:

(e) any amount payable under the Child Support Act 1991.

Discharge represents a return to independence for the bankrupt. During the bankruptcy administration period the Official Assignee has overall responsibility for the bankrupt. If the Official Assignee determines that the conduct of a bankrupt either during or prior to bankruptcy was unacceptable they can apply to the Court to prolong the bankruptcy by denying the bankrupt a discharge. Section 290 of the Insolvency Act states: ${ }^{191}$

\section{Automatic discharge 3 years after bankrupt files statement of affairs}

(1) A bankrupt is automatically discharged from bankruptcy 3 years after the bankrupt files a statement of affairs under section 46 or section 67 , but may apply to be discharged earlier.

(2) However, a bankrupt is not automatically discharged if-

(a) the Assignee or a creditor has objected under section 292 and the objection has not been withdrawn by the end of the 3 -year period referred to in subsection (1); or

(b) the bankrupt has to be publicly examined under section 173 and has not completed that examination; or

(c) the bankrupt is undischarged from an earlier bankruptcy.

\footnotetext{
${ }^{190}$ Insolvency Act 2006, s 304.

${ }^{191}$ Insolvency Act 2006, s 290.
} 
Discharge as a matter of course occurs three years after the filing of the statement of affairs. This automatic discharge has the same effect as if it had been ordered by the Court. ${ }^{192}$ There is the ability for either a creditor or the Official Assignee to object to the automatic discharge under s292. If an objection is raised, the Court must examine the bankrupt. In order for the Court to have the appropriate evidence before it the Official Assignee has to file a report. ${ }^{193}$ This report must contain the following information: ${ }^{194}$

(2) The Assignee must report as to-

(a) the bankrupt's affairs; and

(b) the causes of the bankruptcy; and

(c) the bankrupt's performance of his or her duties under this Act; and

(d) the manner in which the bankrupt has obeyed orders of the Court; and

(e) the bankrupt's conduct before and after adjudication; and

(f) any other matter that would assist the Court in making a decision as to the bankrupt's discharge.

Once armed with this information the Court can make a determination on the appropriate order. The court can either grant or refuse discharge. ${ }^{195}$ The court can also order discharge with restrictions placed upon the bankrupt. ${ }^{196}$ The scope of the Court's discretion has been tested in many historical cases, however in the case of ASB Bank v Hogg the Court of Appeal made the following directive statement: ${ }^{197}$

In conferring a discretion expressed in the broadest terms, the legislation recognises that each case will be different, that the relevant factors may vary from case to case and that the exercise of the discretion must be governed by the circumstances of the particular case having regard to the guidance provided by a consideration of the scheme and purpose of the legislation. In providing for automatic discharge after three years, the legislation recognises that it is not in the public interest that the bankruptcy should endure indefinitely. In providing for earlier discharge, s 108 [see now 294 of the Insolvency Act 2006] recognises that continuing the bankruptcy to the end of the three years may not be in the public interest. Whether or not it is will be a matter for decision on the particular facts. In that regard, guidance is provided by s 109(2) [see now s 296 of the Insolvency Act 2006] which lists matters on which the assignee is to report to the High Court in such a case. The Court is to consider the assignee's report as to the affairs of the bankrupt, the causes of the bankruptcy, the manner in which the bankrupt has performed the duties imposed on him or her under the Act and his or her conduct both before and after the bankruptcy, and also any other fact, matter or circumstance that would assist the Court in making its decision. Clearly the Court apprised of the matter will consider the legitimate interests of

\footnotetext{
192 Section 291.

193 Section 296(1).

${ }^{194}$ Section 296(1).

195 Section 298.

196 Section 299.

${ }^{197}$ ASB Bank v Hogg [1993] 3 NZLR 156 (CA).
} 
the bankrupt, the creditors, and wider public concerns, but it is neither required nor entitled to impose threshold requirements in the exercise of the discretion so as to derogate from the breadth of the powers conferred under s 110 [see now s 298 of the Insolvency Act 2006]. The applicant has the onus, in the sense of adducing evidence, to show good cause for ordering an early discharge, but his obligation goes no further than that.

While this statement did not contain any new material it did encapsulate all of the previous principles in one concise passage. This passage has now become a reference point quoted as precedent in subsequent cases. When $\mathrm{Mr}$ Armitage was brought before the court because of the Official Assignee's objection to his third discharge from bankruptcy, the court further focused on the issues as summarised by Brookers: ${ }^{198}$

(i) The onus is on the Assignee to satisfy the Court that it is in the public interest that the bankruptcy should continue for a further period.

(ii) The Court has a broad discretion which it must have regard to all the circumstances of the particular case.

(iii) In the absence of good reasons, a bankrupt should normally obtain a discharge. However, public interest factors may mean that an order of discharge should be refused.

(iv) Guidance in the exercise of the Courts discretion is provided by s 296(2), which lists matters on which the Assignee is to report to the High Court. Thus, the Court may consider the manner in which the bankrupt has performed the duties imposed on him or her under the Act and his or her conduct both before and after the bankruptcy and any other matters that may assist the Court in making its decision.

(v) The relevant matters therefore include: the interests of the bankrupt; the interests of the creditors; the public interest; commercial morality and the conduct of the bankrupt.

The points summarised above at (v) above provides a concise list of stakeholders. It is quite clear that the competing interests of stakeholders has to be the key determinate of the court when deciding whether to extend the period of bankruptcy rather than granting discharge. Weighing up the various factors including the conduct of the individuals involved will be of paramount importance. In Edwards $v$ Official Assignee ${ }^{199}$ the court based its decision on not granting a discharge based on the conduct of Mr Edwards. Mr Edwards' conduct had been so abhorrent that he was serving a custodial sentence for the very events that had led to his bankruptcy. The

\footnotetext{
${ }^{198}$ Commentary Insolvency Law \& Practice, Brookers Online http://www.brookersonline.co.nz.helicon.vuw.ac.nz/databases/modus/lawpart/statutes/ACT-NZL-PUBY.2006-55 BDY PT.4 SPT.1 SG.!101 S.298?si=57359 last viewed 26 February 2014.

${ }^{199}$ Edwards v Official Assignee 1/4/04, CA236/03.
} 
court acknowledged that the duration of Mr Edwards bankruptcy would exceed seven years but was not satisfied that he did not pose a considerable commercial risk to the business community and the public.

\section{K $\quad$ Fresh Start, Can it Fail to Rehabilitate?}

The concept of the fresh start is that the insolvent is released from their financial burdens and is offered the opportunity to start over without those obligations acting as a millstone. It is important to note that there are some debts that a bankrupt is not released from on discharge in New Zealand. The most important debt that is not provable is Child Support. Although a bankrupt will be discharged from bankruptcy at the end of the prescribed period unprovable debts and obligations will remain in force and are unavoidable.

The humanitarian theory ${ }^{200}$ is based on the concept of rehabilitation. However some of the issues which potentially led to the cause of the bankruptcy may not have been resolved simply because the individual has gone through bankruptcy and discharge process. Statistics from the US indicate that about two thirds of discharged bankrupts move on to being in an improved situation within twelve months of discharge. There does not appear to have been any studies on the equivalent in New Zealand. However the New Zealand Insolvency and Trustee Service does publish annual statistics relating to repeat bankruptcies. In the year ending 30 June 2013, $12 \%$ of the 2188 bankruptcies were repeat bankrupts. From these numbers it is reasonable to assume that there exists an equivalent section of the population in New Zealand that are struggling but have just not re-entered bankruptcy. The concern is obviously the third of discharged bankrupts identified in the US statistics, who feel their financial situation was the same as or worse than when they were bankrupt. Porter and Thorne surmise: ${ }^{201}$

These data highlight a critical reality about the bankruptcy system and should give pause to those who bemoan the generosity of Chapter 7 bankruptcy. The most fundamental assumption of consumer bankruptcy - that the fresh start results in a productive end - is suspect. Life after bankruptcy is not unequivocally better for many families. These findings are a powerful reminder of the limitations of the consumer bankruptcy system.

An insolvency regime's powers of rehabilitation are clearly limited especially where other socio economic factors are present. An individual's poor health, failure to

\footnotetext{
${ }^{200}$ Gross, above $\mathrm{n} 4$ at 131.

${ }^{201}$ Katherine Porter \& Deborah Thorne, "The Failure of Bankruptcy's Fresh Start” (2006) 92 Cornell

L. Rev. 88 .
} 
maintain regular employment, addictions, gambling or inability to live within a budget are all factors that undermine the potential positive outcomes post-bankruptcy discharge. However the two thirds majority still achieve a better outcome after discharge. Discharge with a clean slate must therefore be viewed as a success as the majority are able to escape from the debt cycle.

Regardless of what models are suggested for an insolvency regime, it is acknowledged that there will still be individuals who, for a variety of complicating factors will not escape the insolvency cycle through a clean slate discharge or equivalent mechanism.

\section{Immediate Discharge}

The concept of an immediate discharge is not new. Chapter 7 in the US has been around since 1978 as part of the Bankruptcy Code. Chapter 7 in its purest form allows insolvents a fresh start. Chapter 7 allows for a liquidated bankruptcy. In a liquidated bankruptcy scenario the trustee is responsible for the collection and realisation of assets and distribution of any dividends to creditors. An insolvent who wishes to file a bankruptcy under Chapter 7 does not have to file a plan as to creditor repayment.

In order to be eligible for a Chapter 7 bankruptcy an insolvent must pass a means test. The means test is designed to pick up cases of abuse, where an insolvent is filing merely to escape their legitimate obligations without having to make any form of ongoing contribution. If the insolvent has a "current monthly income" more than the state median the Chapter 7 filing is presumptively abusive. Abuse is presumed if the debtor's aggregate current monthly income over 5 years, net of certain statutory allowed expenses, is more than (1) $\$ 11,725$, or (ii) $25 \%$ of the debtor's non-priority unsecured debt, as long as that amount is at least $\$ 7,025^{202}$. (2) The debtor may rebut a presumption of abuse only by a showing of special circumstances that justify additional expenses or adjustments of current monthly income. Unless the debtor overcomes the presumption of abuse, the case will generally be converted to Chapter 13 (with the debtors consent) or will be dismissed. 11 U.S.C. s707(b)(1). ${ }^{203}$

If a debtor meets the requirements for a Chapter 7 bankruptcy the trustee must within 21 and 40 days hold a meeting of creditors. The insolvent is placed on oath and is subject to questioning from the trustee and or creditors. The trust then will report to

\footnotetext{
20211 U.S.C. $\$ 707(b)(2)$.

${ }^{203}$ United States Courts, "Liquidation Under Bankruptcy Code"

<http://www.uscourts.gov/FederalCourts/Bankruptcy/BankruptcyBasics/Chapter7.aspx > last viewed 27 February 2014.
} 
the court within 10 days on whether the case is presumptively abuse under the means test. $^{204}$

Whilst the principal of a Chapter 7 bankruptcy is that there is immediate discharge this is not the case. The bankrupt is not discharged until after the creditors meeting and the court has had the opportunity to evaluate the case. This usually occurs some 60 to 90 days after the creditor's first meeting. ${ }^{205}$

In proposing an immediate discharge model for New Zealand some context needs to be expanded upon. The insolvent under the proposed model would have already been in a state of personal insolvency for a month or so at this point, as per the model described above. The Official Assignee has already ascertained the insolvent's full financial position and has determined the likelihood of any dividend being available for distribution. If with all of this knowledge the Official Assignee determines that the ongoing cost of administering the bankrupt estate will outweigh any potential recovery, the insolvent has fully cooperated with the process, there exists no question of dishonesty on the part of the insolvent and this is the insolvent's first time utilising an insolvency remedy then they qualify for immediate discharge.

In the interests of optimising the time of the court and to maximise the efficiency of the system it is suggested that the power to administrate the system and grant the discharge should rest with the Official Assignee. The only time the court would need to be involved would be in the rare circumstance where a creditor objected to an immediate discharge. By virtue of the Official Assignee already conducting a thorough examination of the insolvent while in personal administration they were able to report accurately to creditors prior to immediate discharge. If a creditor was dissatisfied with the situation the Official Assignee already had the report to file with the court.

\section{Support for Immediate Discharge}

International models such as the US Chapter 7 (although the process has been complicated by BACPA), Australia between 1991 and 2002, and France all have utilised models of immediate discharge. New Zealand through the reports and recommendations of the Ministry of Economic Development suggested amending the current model to include a discharge after one year for bankrupts who were not guilty of commercial misconduct. ${ }^{206}$ This coupled with actual solutions like the No Asset

\footnotetext{
204 11 U.S.C. s 704(b).

${ }^{205}$ Fed Bankr. P. 4005.

${ }^{206}$ Ministry of Economic Development, above n 172 at 47.
} 
Procedure which was enacted by the legislature, confirm that New Zealand is ready for a system that allows for immediate discharge with the following caveats and or circumstances:

1. That the insolvent has never utilised an insolvency regime previously; and

2. That the insolvent has undergone examination by the Official Assignee under personal administration and the Official Assignee thought the bankrupt was a suitable candidate for early discharge; and

3. That the cost of administration of the bankrupt estate would be greater than any potential recovery.

The key component would be that such an early discharge would be at the discretion of the Official Assignee. There would however be a presumption that early discharge would occur if a creditor met the three general criteria set out above, while it is envisaged that immediate discharge will release the bankrupt from bankruptcy and allow them to start rehabilitation sooner. The existing obligations post discharge would still apply for the bankrupt to assist the Official Assignee or the court. ${ }^{207}$ Further the public records associated with recording the bankruptcy on the Insolvency Register would also remain. ${ }^{208}$

If a creditor was to object to immediate discharge they would still have the same rights as they do now to object to the court under section 292 which has been previously discussed. However the creditor would be holding that view in contrast to the Official Assignee who had already examined the creditor, although it is important that creditors have the right to object to the court. However there should be limits on which objections can be raised. It would be impractical if a creditor raised an objection just because they thought it was not fair or they wanted to get paid. The objection should instead go to the conduct and commercial morality of the bankrupt. It is suggested that by having an express list of grounds for refusing a discharge provides greater certainty for all stakeholders. In the US there is a specific list of grounds for refusing discharge ${ }^{209}$ and it is suggested that similar grounds be adopted in the amended New Zealand model. The suggested wording of this section is:

The court shall grant the debtor a discharge, unless-

(1) the debtor is not an individual;

(2) the debtor, with intent to hinder, delay, or defraud a creditor or the Official Assignee, has transferred, removed, destroyed, mutilated, or concealed, or has permitted to be transferred, removed, destroyed, mutilated, or concealed-

\footnotetext{
${ }^{207}$ Insolvency Act 2006, s 307.

208 Section 308.

${ }^{209} 11$ U.S. Code $§ 727$.
} 
(A) property of the debtor, within one year before the date of the filing of the petition; or

(B) property of the estate, after the date of the filing of the petition;

(3) the debtor has concealed, destroyed, mutilated, falsified, or failed to keep or preserve any recorded information, including books, documents, records, and papers, from which the debtor's financial condition or business transactions might be ascertained, unless such act or failure to act was justified under all of the circumstances of the case;

(4) the debtor knowingly and fraudulently, in or in connection with the case-

(A) made a false oath or account;

(B) presented or used a false claim;

(C) gave, offered, received, or attempted to obtain money, property, or advantage, or a promise of money, property, or advantage, for acting or forbearing to act; or

(D) withheld from an officer of the estate entitled to possession under this title, any recorded information, including books, documents, records, and papers, relating to the debtor's property or financial affairs;

(5) the debtor has failed to explain satisfactorily, before determination of denial of discharge under this paragraph, any loss of assets or deficiency of assets to meet the debtor's liabilities;

(6) the debtor has refused, in the case-

(A) to obey any lawful order of the court or Official Assignee, other than an order to respond to a material question or to testify;

(B) on the ground of privilege against self-incrimination, to respond to a material question approved by the court or Official Assignee or to testify, after the debtor has been granted immunity with respect to the matter concerning which such privilege was invoked; or

(C) on a ground other than the properly invoked privilege against selfincrimination, to respond to a material question approved by the court or Official Assignee or to testify;

(7) the debtor has committed any act specified in paragraph (2), (3), (4), (5), or (6) of this subsection, on or within one year before the date of the filing of the petition.

(b)

(1) The Official Assignee or a creditor may object to the granting of a discharge under subsection (a) of this section.

(c) On request of the Official Assignee or a creditor, and after notice and a hearing, the court shall revoke a discharge granted under subsection (a) of this section if-

(1) such discharge was obtained through the fraud of the debtor, and the requesting party did not know of such fraud until after the granting of such discharge;

(2) the debtor acquired property that is property of the estate, or became entitled to acquire property that would be property of the estate, and knowingly and fraudulently failed to report the acquisition of or entitlement to such property, or to deliver or surrender such property to the Official Assignee;

(3) the debtor committed an act specified in subsection (a)(6) of this section;

or

(d) The Official Assignee or a creditor may request a revocation of a discharge-

(1) under subsection (c)(1) of this section within one year after such discharge is granted; or

(2) under subsection (c)(2) or (c)(3) of this section before the later of-

(A) one year after the granting of such discharge; and

(B) the date the case is closed. 
This suggested wording focuses an express list of grounds for refusal to grant discharge or for retrospectively cancelling a discharge that was obtained through the dishonesty of the bankrupt. By focussing the grounds for refusal on the honesty and morality of the bankrupt the grounds for refusal are limited. Such a system would result in an honest bankrupt being eligible for discharge while dishonest bankrupts would remain undischarged. This system is not designed to be punitive but has its foundations based on protection of the public and business community. If the dishonesty that formed the basis of the refusal to grant discharge was criminal then such instances could be prosecuted. Any conviction for such an act of dishonesty would have a sentence that would be punitive. A system of tandem incentives and punitive remedies should act as the proverbial carrot and the stick to encourage compliance with the regime.

A liquidated bankruptcy with an immediate discharge is argued as being a useful tool for all stakeholders. Bankrupt estates that have no assets or with assets that have or will be easily realised but will still result in no prospect of a dividend should be quickly dealt with to ease congestion within the system. Focus can then be given to bankrupt estates that require a level of management and value extraction. The New Zealand Insolvency and Trustee Service does not keep records of the percentage of cases where a dividend is paid. However they can confirm that the Official Assignee distributed dividends of $\$ 14,753,627.10$ to creditors in the year ending 30 June 2013. ${ }^{210}$ Bankrupts who have conducted their affairs without misconduct will enjoy the rehabilitative relief from discharge sooner, thereby encouraging sound and positive behaviour. Those bankrupts that have acted recklessly or have committed an act of misconduct will face a longer period before discharge. Creditors benefit from the knowledge that the matter has been fully investigated by the Official Assignee and can have confidence in the outcome. The public interest and commercial morality are both protected through the incentive of early discharge for those that conduct their affairs well. Those bankrupts guilty of some form of misconduct are denied the relief of discharge until the traditional three year period has elapsed or until the court orders its discharge, whichever is the longer. The only potential risk to the optimal operation of this suggested alternative is if the Official Assignee fails to exercise their duties correctly. If a question arose as to the correctness of the discretion granted to the Official Assignee under these provisions, the matter could be resolved by the Court.

This change to the discharge provisions should not be viewed as a punitive measure for bankrupts that do not conduct their affairs well. Instead it should be

\footnotetext{
${ }^{210}$ Insolvency and Trustee Service Insolvency Statistics and Debtor Profile Report (1 July 2012 to 30 June 2013) at page 7. Able to be viewed at http://www.insolvency.govt.nz/cms/site-tools/aboutus/statistics/statistical-data-reports/ITS-Statistical-Data-Report-12-13.pdf
} 
viewed as a reward for those that do conduct their affairs well, thereby encouraging all individuals to be vigilant in conducting their financial affairs.

This is not a proposed new alternative, in fact it is the status quo for all insolvencies that enter the personal insolvency gateway and for whatever reason fail to be shepherded down a different path. As noted above this traditional bankruptcy is not a punitive measure in itself, it just means that an individual does not qualify for early discharge. If the Official Assignee wants to impose punitive or public protection type conditions on a bankrupt, then that would be deemed to be a punitive measure because of the bankrupt's previous bad acts.

In many cases it is accepted that the traditional bankruptcy will not yield a greater return for creditors. This in itself is not an issue, for it is suggested that the benefit is the incentive to conduct ones affairs better in the first place. Further where external factors have hampered a bankrupt from being financially stable, a longer bankruptcy term can allow time for such stability to be found. Australia, which is arguably the closest jurisdiction to New Zealand also has a three year bankruptcy before discharge. When Australia used an immediate discharge model there were no floodgates opening to increased insolvency numbers. There was also as discussed by John King no empirical reason why bankruptcy should last any particular length. ${ }^{211}$ Further there appears to be no reason for the removal of the immediate discharge provisions. Traditional bankruptcy is still the option of last resort, and it is suggested that the model of a personal administration proposal will in fact have strong uptake and will be the insolvent's preferred alternative.

\section{Personal Administration}

Personal administration will be championed as the best solution for the majority of insolvents who wish to avoid bankruptcy but are still unable to meet their financial commitments. There is recognition that the liquidated bankruptcy models discussed above, with immediate discharge and traditional discharge, fail to provide a solution in all insolvency situations. This failure of the current system to recognise the key purposes of an insolvency regime from a stakeholder's perspective will be used to support the need for insolvency reform. The pre-bankruptcy area of insolvency will be advanced as being the key area for reform. The reform recommendation advanced to achieve an optimal regime is personal administration, thus; using Korobkins' 'critical

${ }^{211}$ King, above $n 5$. 
reform' that "critical claims about [insolvency] purposes are [the] framework for reform." 212 The framework suggested in this section is that of personal administration.

The concept of personal administration as advocated in this paper will be discussed and described with the process outlined in a step-by-step manner. Then the system of personal administration will be critiqued from the perspective of each of the identified stakeholders. Finally, this section will conclude with an analysis of personal administration using the economic theories, balanced approach and utilitarian framework as already outlined.

In 2006 New Zealand brought in the first legislated alternatives to bankruptcy with the introduction of the "No Asset Procedure'213. This option provided for the first time, a meaningful alternative to bankruptcy (if insolvents met the prescribed criteria). At the same time, the Companies Act 1993 was also was amended to include provision for 'Voluntary Administration'214.

These two changes showed a shift in attitude by the legislature away from a punitive insolvency regime towards a rehabilitative one. Whilst these reforms have not gone anywhere near as far as reforms in other jurisdictions they clearly signal a new approach. These reforms have not gone anywhere near as far as the recommendations made by the Ministry of Economic Development. ${ }^{215}$ They have however clearly demonstrated a change in attitude by the legislature. This new approach for personal insolvency allows individuals the ability to deal with their personal debts in a manner that does not attach the moral stigma of bankruptcy to the individual while still offering them a 'clean slate'. From a corporate perspective voluntary administration "provides for the administration of the business and affairs of insolvent or near insolvent companies"216

The provision of alternatives that do not contain the words 'bankruptcy' or 'liquidation' is a major advance on the historical treatment of insolvents. The new options have become more acceptable to the public morality because of the lack of labels attached to them. These alternatives to bankruptcy may achieve the same result

\footnotetext{
212 Korobkin, above n 4 at 83.

213 Section 361 .

${ }^{214}$ Companies Act 1993, Part 15A s 239.

${ }^{215}$ Ministry of Economic Development Insolvency Law Review: Tier One Discussion Documents

(Ministry of Economic Development, Wellington, 2001).

${ }^{216}$ Paul, Heath and Michael, Whale, above n 85 at 329.
} 
in terms of creditor returns without the insolvent having the stigma of being labelled a bankrupt.

The corporate model of voluntary administration provides, according to Heath and Whale: ${ }^{217}$

\footnotetext{
The administrator of a company has control of its business property and affairs while it is under administration (s 239U(a)). He or she, as the company's agent (s 239W) may carry on its business, manage its property and affairs, close its business, sell any of its property and otherwise perform any function or exercise any power which the company or any of its officers could have exercised had the company not been under administration.
}

Voluntary administration is entered into on a voluntary basis by the directors of a company. There exist only two options for a company that has entered voluntary administration, liquidation or release back to its directors. For directors there is an incentive for placing a company in the hands of an administrator, in that the company may be able to be rehabilitated without the directors incurring personal liability from risking insolvent trading.

\section{B The Process of Personal Administration \\ $1 \quad$ Entry}

The proposed system of personal insolvency as outlined above would be a compulsory precursor to bankruptcy or personal administration. There would be two clearly defined entry points to personal insolvency, either an insolvent has filed a petition with the Official Assignee or an insolvent has committed an 'act of bankruptcy' by failing to comply with a 'bankruptcy notice'218. On the occurrence of either of these events the insolvent would automatically enter personal insolvency. This would immediately take away any need for a creditor to incur the additional costs associated with petitioning the court for adjudication. It would also remove the often long drawn-out process associated with insolvents trying to piece together compositions or compromises under the $2006 \mathrm{Act}^{219}$. Instead personal administration would provide mechanisms for the insolvent to present proposals to creditors.

On entry to personal insolvency the insolvent's property would vest in the Official Assignee in a similar manner to bankruptcy ${ }^{220}$. This vesting would only be a temporary measure while the Official Assignee assessed the insolvent's situation and

\footnotetext{
217 At 361.

218 Section 17.

219 Section 326.

${ }^{220}$ Section 101.
} 
prepared a report to creditors. There would be only three possible outcomes to a personal insolvency; either bankruptcy, personal administration or release (if it was found the debtor was not insolvent).

Adopting an administrative gateway system to bankruptcy, potentially adds an additional layer of expense to the administration of insolvent estates. It will be argued that some additional expense will be offset by the savings to creditors in no longer having to petition the Court. Public protection from the further dealings of insolvents also provides an intangible benefit to society as a whole. In the case of Henderson. ex parte Commissioner of Inland Revenue ${ }^{221}$ the Court emphasised this public protection aspect.

\section{$2 \quad$ Statement of affairs}

There would be an immediate requirement for a 'Statement of Affairs' ${ }^{222}$ to be filed by the insolvent (as is currently required in a bankruptcy situation) and it would be compulsory to file within time frames specified in the $\mathrm{Act}^{223}$.

From the statement of affairs the Official Assignee would be able to determine the total indebtedness of the insolvent, the assets of the insolvent and the security of any creditor. The Official Assignee would then search the various security registers to identify any registered priorities. The Official Assignee would also be able to determine which parties or entities are related to the insolvent.

It is important at this point that the Official Assignee scrutinises each creditor and puts them to proof of their debt. This is an important step as it filters any potential circumvention of the process through stacking the deck with 'fictitious creditors'. The case of Henderson. ex parte Commissioner of Inland Revenue ${ }^{224}$ is an example of where, amongst other reasons, unproven debts and liabilities were rejected by the Court, even though on the surface the numbers supported ratification of the proposal.

At this point the Official Assignee would interview the insolvent, with a view to answering any questions raised in the statement of affairs. The Official Assignee would then be obliged to explain the options to the insolvent (the options being bankruptcy or personal administration). Insolvents currently can only access proposals or compositions as alternatives to place before the Court, however very few do so. The main reason for this appears to be lack of legal representation by insolvents at

\footnotetext{
${ }^{221}$ Henderson. ex parte Commissioner of Inland Revenue (2011) 25 NZTC 20049 (HC) at [56].

${ }^{222}$ Section 68.

${ }^{223}$ Section 69.

${ }^{224}$ Henderson. ex parte Commissioner of Inland Revenue, above n 15, at [50].
} 
bankruptcy proceedings. This implies that most insolvents are not able to access legal advice on their options prior to bankruptcy court.

The Official Assignee would then report to creditors based on the information outlined above.

\section{Official assignees report}

The Official Assignee's report would include details of the likely distribution from any bankruptcy including an estimate of the Official Assignee's expected costs. It would also contain any proposal that the insolvent wished to make.

The Official Assignee's role would be to report on the facts discovered from the statement of affairs and its enquiries and also report the facts contained in any proposal. It is expected that the Official Assignee will be involved in the development of the proposal. The Official Assignee's involvement will ensure that the proposal is the best offer that the insolvent can put before creditors. The Official Assignee will only place a proposal before creditors if the Official Assignee believes that the proposal should be approved. Conversely the Official Assignee should not allow a proposal to be presented to creditors that it does not support. If a personal administration proposal is presented the Official Assignee is obliged to inform the creditors of the alternative should the proposal be rejected. In most cases it is assumed that the alternative will be a liquidated bankruptcy with no dividend and immediate discharge.

If the Official Assignee suspects misconduct, fraud or dishonesty on the part of the insolvent it must not report to the creditors until these matters have been investigated. If any such conduct is discovered the Official Assignee has an obligation to report it to the creditors and must place the insolvent immediately into traditional bankruptcy.

\section{Creditors meeting}

Within a finite practical time frame (which will largely depend on the size of the insolvency and the number of creditors and other parties involved) the Official Assignee must call a creditors meeting. The purpose of the meeting is to hold a vote on the proposal if one has been presented by the insolvent. Voting would be a largely 
symbolic exercise as the Official Assignee would have the power to automatically approve the personal administration proposal under the following criteria:

The personal administration proposal was set to last 36 months;

The personal administration proposal allowed for at least $90 \%$ of the insolvent's after legitimate expenses income being contributed to the proposal; or

The insolvent added assets to the pool that would not have been available to creditors, in a value of not less than $5 \mathrm{c}$ in the dollar of accepted proven debts; or

The total return to creditors from all sources is greater than 10c in the dollar of accepted proven debts.

On these bases it is reasonable for the Official Assignee to push through the personal administration proposal because it yields a better outcome for the general body of creditors. However the vote should still take place so the Official Assignee can ascertain the response and feedback from creditors. Voting would be able to be done via postal ballot for those creditors that opt not to attend the meeting.

The proposed model does not include any provision for a cram-down mechanism to be incorporated as mandatory. Instead the personal administration program is flexible to allow any and all eventualities. If insolvents with the support of the Official Assignee want to present a creditor cram-down scenario contained within the personal administration proposal, they could do so. If such a proposal was endorsed by the Official Assignee then it could also be forced upon creditors.

In the development phase of the model of a personal administration proposal, the thesis was going to take the approach that the creditor vote acted as a veto on an unpopular proposal. However after examining overseas jurisdictions, it appears that jurisdictions where the local trustee has the power to approve an insolvency proposal the systems run substantially more efficiently. A good example of such jurisdiction is the French model. ${ }^{25}$ As such the model has developed to allow the Official Assignee the power to force a personal administration proposal to be approved.

Voting is still an important aspect of the process so creditors feel involved in the process. Voting would be on a simple majority basis of $50 \%$ based on value of the debt or by simple majority of $50 \%$ on number of creditors. This threshold is lower than in the current Act and its predecessors. Although the voting is now symbolic only and its result have no legal effect, it still engages the creditor in the process and

${ }^{225}$ Kilborn, above n 160. 
creates closure for them. Including the creditors is a deliberate move designed to promote better education of insolvency procedures so creditors can in the future better manage their debtors.

The current system whereby the minority of creditors (often just one) applies to the Court for an adjudication of an insolvent, does not recognise the interests of the balance of creditors who are not party to the court proceedings. Although the fate of the insolvent now lies exclusively with the Official Assignee it is important to engage creditors in the process. Thus personal administration provides an element of natural justice in that all stakeholders are involved in the process even if they do not have ultimate control over the outcome.

If during the voting phase creditors bring new evidence to the attention of the Official Assignee that alters its view on the personal administration proposal, the Official Assignee is able to withdraw its support of the proposal and instead bankrupt the insolvent using one of the two previously discussed bankruptcy models.

\section{Official assignee must approve the personal administration proposal}

Although the Official Assignee is the party with the sole power to approve or reject a proposal, before they approve the proposal it should be required to see whether the proposal is acceptable to creditors, as per the proposed amendment. It is suggested that the model for such a check list be similar to that of section $333^{226}$. The suggested amendment would be worded as follows:

\section{Official Assignee must approve proposal}

(1) The Official Assignee must, before approving a proposal, hear any objection that is made by or on behalf of a creditor.

(2) The Official Assignee may refuse to approve the proposal if it considers that-

(a) the provisions of this subpart have not been complied with; or

(b) the terms of the proposal are not reasonable or are not calculated to benefit the general body of creditors; or

(c) for any reason it is not expedient that the proposal be approved.

(3) When it approves the proposal, the Official Assignee may correct any formal

\footnotetext{
${ }^{226}$ Insolvency Act 2006, s 333.
} 
or accidental error or omission, but must not alter the substance of the proposal.

This process would also allow any creditors who did not approve the proposal to state their objections to the Official Assignee. If the Official Assignee still approved the proposal it would bind all of the insolvent's creditors regardless of whether they voted for or against the proposal.

\section{Judicial Support}

New Zealand courts see proposals or compositions put before them in two distinct circumstances, either prior to bankruptcy or post-bankruptcy. The proposals made prior to bankruptcy are made under sections 325 to $339^{227}$, while the compositions made during bankruptcy are made under sections 312 to $324^{228}$. Neither of these alternatives feature in the statistics published by the Insolvency and Trustee Service. Part of the reason for this is the use of both mechanisms has historically been very limited. Most individuals once bankrupt accept their situation and see no merit in advancing a composition. The majority of those who do try to advance a composition do so unsuccessfully.

Proposals have historically been the domain of the super wealthy or professionals whose income is tied into their ability to be able to continue to work. The vast majority of these cases involve commercial and business insolvencies. The sums involved are also substantial. Many of the proposals made under Part 5 involve parties that are related to the insolvent or at least have a substantial investment in the outcome of the proceedings. Cases like Henderson ${ }^{229}$ involve substantial sums, in that case over one hundred million dollars. Many of the creditors who supported the proposal held securities and were going to benefit from other substantial related transactions that $\mathrm{Mr}$ Henderson had relating to other developments.

It is also recognised that proposals can be used as a mechanism to allow an insolvent to continue to trade or operate in a profession, where if they were bankrupt they would not be able to. In the case of $\operatorname{Re} W e b b^{230}$ a former lawyer advanced a proposal which was approved by all creditors including the IRD and the New Zealand Law Society. By approving the proposal Mr Webb was able to to leave New Zealand to work in the Bahrain as a tutor and was able to make payments to his creditors over three years that resulted in a dividend of $100 \%$ to priority creditors and $36 \%$ to

\footnotetext{
${ }^{227}$ Insolvency Act 2006, ss $325-339$.

${ }^{228}$ Sections $312-324$.

${ }^{229}$ Henderson, ex parte Commissioner for Inland Revenue (2011) 25 NZTC 20-049.

${ }^{230}$ Re Webb [2013] NZHC 523.
} 
unsecured creditors. At the time when the proposal was approved Mr Webb had assets of only $\$ 5,000$ and so his creditors would have suffered a complete loss. Likewise the case of $R e$ Meyer $^{231}$ a real estate agent who got involved in a failed commercial property development through the association of the partner was able to have a proposal approved. This again allowed Ms Meyer the ability to continue in her role as a leading real estate sales person so that she could make repayments to creditors under the part 5 proposal.

The Court has generally adopted a pragmatic view that if the proposal is supported by creditors using their commercial acumen then the court should trust their decision. This point has been reinforced in the recent appeal case of Herbert $v$ New Zealand Guardian Trust Co Ltd ${ }^{232}$ which quoted this passage from Re Bennetts ${ }^{233}$

\begin{abstract}
... Rather than it being for the proponents of a scheme to show that it ought to be approved, I think the Court should accept the view of the creditors, or the majority of them, and grant approval unless it is apparent that one of the grounds for refusing approval exists. The Court is clearly required to exercise its independent judgment, for considerations of wider public interest are relevant, and therefore even unanimity amongst the creditors will not be predeterminative of approval. But unless it is clear that the creditors generally would fare better under a bankruptcy, approval ought normally to be given unless other special circumstances militate against it. Whilst a proposal ought not to be imposed upon dissentient creditors if that would be advantageous to them as members of the general body of creditors their dissent should not be upheld if to do so could be prejudicial to the general body of creditors.
\end{abstract}

Although the suggested model of personal administration gives the Official Assignee the power to approve even an unpopular proposal, the Official Assignee does still have to hold a vote and allow creditors the opportunity to object to the proposal. If creditors in the majority reject the personal administration proposal and offer valid reason for their objections, the Official Assignee can, if it sees merit, alter its view and remove its support of the proposal. However if the Official Assignee is not swayed by the arguments of creditors then it can still force the proposal through.

\title{
D $\quad$ Secured Creditors
}

Secured creditors have always held a unique position within any insolvency regime. They are affected by the situation but their actual exposure is not known as the underlying security has not had its value tested in the marketplace. Therefore the potential loss is unable to be quantified. This in part explains why secured creditors have had their respective voting rights fixed under Part 5 proposals at the total debt at

${ }^{231}$ Re Meyer [2013] NZHC 399.

${ }^{232}$ Herbert v New Zealand Guardian Trust Co Ltd [2012] NZCA 442 at 27.

${ }^{233}$ Re Bennetts HC Christchurch B138/81; M306/81, 1 February 1982 at 9 
the time when the proposal is filed with the Court. ${ }^{234}$ If assets are subsequently sold or disposed of either by the creditor or the insolvent and the debt is reduced accordingly the voting rights are not amended unless the proposal is amended.

As discussed earlier one of the most powerful provisions of Chapter 11 is the ability of the insolvent to retain their home. ${ }^{235}$ If a property was owned by a family trust which are prevalent in New Zealand, and the trust assets were beyond the scope of the Official Assignee, then the insolvent could legitimately rent the property from the trust and this rent could be used by the trust to meet mortgage payments. If the property was in the personal name of the insolvent then depending on the level of equity and if the property was owned in sole, joint or as tenants in common, the result would be assessed on a case by case basis. If the cost of realising the insolvent's share in the property was going to yield little or no return to creditors then there would be no point including the sale of the property as part of the proposal. Equally if a family member or some other third party was prepared to contribute funds into the personal administration which would not form part of the insolvent's bankrupt estate, they could do so on the express condition that the equity in the property was not to be pursued.

Ultimately it is up to the insolvent and the Official Assignee to work together to develop a plan that maximises the return to creditors that is over and above what they would hope to receive through a liquidated bankruptcy.

E

Theoretical Support

The humanitarian approach, the economic approach and the balanced approach and their associated theories all support the rehabilitation of insolvents although they reach this conclusion by differing methods the outcome is nevertheless one of support. It is argued that personal administration would be supported by all of these approaches.

The humanitarian approach has previously criticised the lack of alternatives within insolvency regimes. ${ }^{236}$ Under the proposed amendments of immediate discharge and personal administration two new tools are added for dealing with insolvency. The power of the personal administration model is that the insolvent is able to keep working and remain a productive member of society during their personal administration. Further the insolvent is incentivised to increase their

\footnotetext{
${ }^{234}$ Insolvency Act 2006 ss 243 and 325.

${ }^{235}$ Chapter 11

${ }^{236}$ Gross, above n 4.
} 
production as they personally are able to keep more while still satisfying their obligations to creditors.

The humanitarian approach supports the concept of personal administration, firstly by increasing the production and self worth of the insolvent during the administration and secondly by allowing them a clean slate release from their obligations at the conclusion of the administration.

The economic approach as advocated by Jackson supports the view that a debtor borrows against their future income in order to maintain a constant level of consumption. The issue with bankruptcy is that in many cases the bankrupt's future income ceases to be able to be included. Further the bankrupt is not incentivised to maximise their income. Under personal administration both these limitations are overcome. The insolvent during administration is able to contribute their income into their insolvent estate, thereby satisfying this principal of the economic approach. Further by the insolvent contributing a greater amount than would otherwise be returned from a bankruptcy the insolvent is aiding is keeping the cost of credit down for the entire community, in that it is a feature of the economic theory that the cost of credit has priced in the potential cost of bankruptcy or loss. A system where it is easy to escape form credit obligations results in credit being more expensive. Under personal administration the incidence of return of funds borrowed thereby reduces the cost of credit because losses are mitigated.

The balanced approach as discussed by King is focused on the balancing of the competing interest of the divergent stakeholders. Value maximisation goes beyond the simple dollar value directly extracted from a debtor in an insolvency for the benefit of the creditors. Wider considerations such as the rehabilitation of the insolvent and their motivated return to the workforce/employment have wider benefits to society in general. If an insolvent enters into a personal administration then they are already contributing to their creditors more than would otherwise be available through their bankrupt estate. The purpose of personal administration is to provide a larger pool of assets to creditors than would otherwise be available. This by default has to support value maximisation for the stakeholders.

The insolvent also benefits from the personal administration through not incurring the stigma of bankruptcy. Also the insolvent may, depending on the nature of the plan, be able to retain significant property that would otherwise form part of their bankrupt estate. The public have confidence in the robust nature of the system because it is operated and sanctioned by the Official Assignee. The moral public and the business community are satisfied that the insolvent has undergone examination 
prior to entering into personal administration, thereby alleviating the risk of a dishonest insolvent receiving a benefit under the scheme.

Personal administration also satisfies Kalder-Hicks in that the financial value extracted from the insolvent is maximised through the administration process. Personal administration is therefore Kalder-Hicks efficient.

\section{F. $\quad$ Examples of Personal Administration}

The mechanics of the proposed reforms of personal insolvency and personal administration are set out in this section. A debtor or creditor petition causes the insolvent to pass into personal insolvency. Once in personal insolvency the individual provides a statement of affairs to the Official Assignee. After an examination of the insolvent the Official Assignee would shepherd the insolvent down one of the three paths of either personal administration, liquidated bankruptcy with immediate discharge or liquidated bankruptcy with traditional discharge. The existing alternatives of proposals, summary instalment orders and no asset procedures are still all retained as alternatives for pre-personal insolvency intervention.

Now that the proposed model of personal administration has been explained it is important to see how different scenarios would play out under this model and compare the results to the status quo.

\section{Example 1-Consumer Insolvent}

This first example provides for a new immigrant to New Zealand. They are skilled and are able to earn a solid income in the IT sector as an independent contractor. They have emigrated from South Africa and have arrived in New Zealand with no assets but strong income. They own no real estate but have acquired a range of consumer chattels on finance and credit card. Because of their strong earning capacity they find access to credit easy.

The insolvent fails to make adequate provision for income tax as a contractor. The insolvent changes their employment status and becomes an employee, doing the same work for a solid fixed salary. The Commissioner for Inland Revenue issues proceedings and a garnishing order is made against the insolvent's wages. The insolvent now has no capacity to maintain the cost of their financial commitments. 
They owe the Commissioner a priority debt of $\$ 20,000$ and consumer finance companies another $\$ 80,000$. The value of the second hand chattels is negligible.

Under a traditional bankruptcy model the insolvent would be adjudicated bankrupt by debtor petition and all creditors would suffer a complete loss. It is also likely that the bankrupt will probably immigrate again to Australia at the first opportunity to restart their life again afresh. Personal administration works very well for this individual. They have a solid reliable income stream which they are able to use to contribute to their personal administration. They have no assets that have any realisable value so no assets are sold instead regular payments are made over a period of 36 months by the insolvent. At the conclusion of the administration the insolvent is released with a clean slate and no lingering bankruptcy on their record. They are free to continue to make a new life in New Zealand and their creditors have received back a considerable portion of their debt.

\section{Example 2- Consumer Insolvent Who Suffers a Health Problem}

An average kiwi worker employed on an average wage of $\$ 50,000$, suffers a heart attack in his mid-forties and has to take a year off work to recover. The individual owns their own home jointly with their wife with a mortgage at $80 \%$ of the value of the property which is valued at $\$ 300,000$. The insolvent also has vehicle finance and credit card debt of $\$ 25,000$. The wife does work and she earns $\$ 35,000$ per annum. As a family they cannot meet all their finance costs and living costs. In the first instance they prioritise repayment of the mortgage but are unable to maintain this on the single income. They obtain a mortgage holiday from their bank which lasts for three months, at the conclusion of this they are unable to meet their financial commitments. The house is subsequently sold at mortgage sale with an additional loss of another $\$ 30,000$.

Under the current law bankruptcy would again yield no dividend. It is also clear that this debtor has not committed any act of dishonesty and it is just bad luck that they find themselves in this situation.

In this situation personal administration would not be the best tool to use. It would make far more sense for this insolvent to be bankrupted with immediate discharge from the personal insolvency. There is no prospect that this insolvent would be able to offer any financial benefit to creditors because of the uncertainty over his health issues. Further this situation deserves the immediate relief that immediate discharge with no further obligations brings.

\section{3. $\quad$ Example 3 - The Failed Business}


A businessman who has previously been moderately successful suffers a relationship breakdown and has to borrow additional funds to buy out his former partner from relationship property including his business, house and chattels. On legal advice post division of relationship property the businessman places his house in a family trust and commences a legitimate gifting program. The recession hits and the business becomes insolvent and is closed down leaving creditors out of pocket for the sum of $\$ 250,000$ which the businessman has personally guaranteed. The trust has a mortgage on the $\$ 500,000$ house for $\$ 250,000$. It is accepted by the Official Assignee that the trust assets would not form part of the insolvents estate should bankruptcy ensue. The business man is able to find new employment earning $\$ 60,000$. The businessman has some new ideas and would like to set up a new business at some point in the future.

Under the current bankruptcy regime the insolvent would be bankrupted over the personal guarantees. His trust assets would remain beyond the reach of the Official Assignee and his creditors would suffer a complete loss. As an undischarged bankrupt no matter how sound the new business idea was the businessman could not set up the business.

Under personal administration the insolvent could if he wanted to, borrow money from the trust and use it to pay his creditors a lump sum of say $\$ 50,000$. Since these are funds that the creditors would not be able to benefit from in a liquidated bankruptcy it is likely that the Official Assignee would recommend the approval of such a proposal. The businessman would then be free to advance his new business venture if he so wanted.

\section{Summary of Examples}

Under all of the examples mentioned above, all creditors ended up in at least as good a position as they would have been under a traditional bankruptcy. The insolvents all ended up in a preferable position. In example 2, even in situations where there is no possibility of a dividend, the insolvent had the opportunity to be discharged from his debts immediately, there being no reason for him to not be discharged.

More options and flexibility that an insolvency regime can contain leads to better outcomes for all stakeholders. Creditors receiving a higher dividend is a positive outcome. Insolvents able to be incentivised to perform as active members of society and to earn and retain any extra wealth they produce is also a positive. Those in unfortunate situations, where honest intentions lead to losses being suffered with no 
act of dishonesty, should be able to be discharged from their obligations quickly so they can work on improving their situation without the millstone of unaffordable financial obligations.

\section{Conclusion}

New Zealand does have an insolvency regime that has had some positive amendments made to it with the Insolvency Act 2006 improvements. The Ministry of Economic Development reports ${ }^{237}$ that led to the development of the 2006 Act did recognise the short comings of the previous legislation. Unfortunately many of the recommendations failed to eventuate in the final legislation. It is this absence of viable alternatives that restricts New Zealand's insolvency systems.

International trends along with New Zealand statistics have indicated that insolvency is increasing the domain of over indebted consumers. Therefore any recommendations for amendment need to be advanced in a framework that targets this group. International trends also supported a general relaxing of the entry criteria to insolvency systems. The historical link between morality and insolvency has been broken and insolvency has been recognised as a social problem that needs addressing. Systems focusing on insolvent rehabilitation that have ease of access coupled with a fresh start on discharge are argued as the best model. Immediate discharge for the honest insolvent is developed as the best mechanism where bankruptcy is unavoidable.

Bankruptcy should have alternatives. The alternative of personal administration has been developed and advanced in this paper as the best alternative to bankruptcy, in that it provides a great value to all stakeholders. Some of the value is quantifiable like the dollar return to creditors. However some of the value is nebulous like the benefit to the insolvent of not being bankrupt but still valuable. Personal administration provides for a non-bankruptcy solution that is flexible enough to be developed around the profile of each insolvent applicant. The proposed model of personal administration run in conjunction with an insolvency gateway as described provides for a model that is efficient in regards to Kalder-Hick and fits within the accepted ideals of the balanced, economic and humanitarian approaches and theories. 
The model of personal administration advanced in this piece is a theoretical model but it is based on extracts from various real world systems. The use of the Official Assignee over the Court to manage the program and debtor and creditor interests, comes from the French system. The US Chapter 13 provides from the mechanism for cram-down as a potential option and provides the basis for an insolvent being able to retain assets through making additional contributions to their estate. Many of the mechanical steps of compositions are already and have historically been part of New Zealand law, thereby creating a normative backdrop to these recommended amendments. Finally the Ministry of Economic Development made a number of suggestions in its reports on insolvency law reform. Many of these reform components feature as part of the model of personal administration. 


\title{
BIBLIOGRAPHY
}

\author{
A Cases \\ $1 \quad$ New Zealand
}

ASB Bank v Hogg [1993] 3 NZLR 156 (CA).

Re Bennetts HC Christchurch B138/81; M306/81, 1 February 1982

Edwards v Official Assignee 1/4/04, CA236/03.

Henderson, ex parte Commissioner for Inland Revenue (2011) 25 NZTC 20-049.

Herbert v New Zealand Guardian Trust Co Ltd [2012] NZCA 442.

Re Meyer [2013] NZHC 399.

Re Webb [2013] NZHC 523.

Salomon v Salomon \& Co [1897] AC 22.

2. $\quad$ United States

Associates Commercial Corp v. Rash 520 U.U. 953 (1997).

Nobleman v. American Savings Bank 508 U.S. 324 (1993).

B Legislation

$1 \quad$ New Zealand 
Bankruptcy Act 1883.

Companies Act 1993.

Consumer Guarantees Act 1993.

Insolvency Act 1967.

Insolvency Act 2006.

Student Loan Scheme Act 1992

$2 \quad$ Australia

$3 \quad$ United States

11 U.S.C. $\S \S 101-1532$.

The Bankruptcy Abuse Prevention and Consumer Protection Act 2005.

$4 \quad$ United Kingdom

1697 Act, 8, 9 Will III, cl 8.

Bankruptcy Consolidation Act 1825 (UK).

Insolvency Act 1976 (UK).

C Bills

$1 \quad$ New Zealand

Insolvency Law Reform Bill 2005 (No 14-1) (Explanatory Note, General Policy Statement). 
D Regulations

$1 \quad$ New Zealand

Insolvency (Personal Insolvency) Regulations 2007.

E Books and Chapters in Books

Fleur Baker and Ralph Simpson, Creditors' Remedies (Continuing Legal Education Department of the New Zealand Law Society, 2001).

David Brown and Thomas G W Telfer, Personal and Corporate Insolvency Legislation Guide and Commentary to the 2006 Amendments (Lexis Nexis New Zealand Limited, Wellington, 2007).

Frank Easterbrook \& Daniel Fischel, The Economic Structure of Corporate Law (Harvard University Press, 1991).

John Farrar \& Lynne Taylor, Company and Securities Law in New Zealand (Thompson/Brookers, Wellington, 2008).

M D A Freeman Lloyd's Introduction to Jurisprudence (Sweet and Maxwell, London, $7^{\text {th }}$ ed, 2001).

Karen Gross, Failure and Forgiveness: Rebalancing the bankruptcy system (Yale University Press, New Haven, Connecticut, 1997).

Paul Heath and Michael Whale, Insolvency Law in New Zealand (Lexis Nexis New Zealand Limited, Wellington, 2011).

Thomas H Jackson, The Logic and Limits of Bankruptcy Law (Harvard University Press, Cambridge Massachusetts, 1986).

David Milman, Personal Insolvency Law, Regulation and Policy (Ashgate Publishing Limited, Aldershot, England, 2005).

Jason Neyers, "Canadian Corporate Law, Veil-Piercing and the Private Law Model Corporation" (2000) 50 University of Toronto Law Journal at 213. 
Ian Ward, An Introduction to Critical Legal Theory (1 ${ }^{\text {st }}$ ed, 1998).

Jacob S Ziegel, Comparative Consumer Insolvency Regimes: A Canadian Perspective (Hart Publishing, Portland 2003).

\section{F Journal Articles}

Helen Anderson, "Creditors Rights of Recovery: Economic Theory, Corporate Jurisprudence and the Role of Fairness" (2006) 30 Melbourne U. L.R. 1.

Stephen Bainbridge, "Community and Statism: A Conservative Contractarian Critique of Progressive Corporate Law Scholarship” (1997) 82 Cornell L. Rev. 856.

Douglass Boshkoff, "Limited, Conditional, and Suspended Discharges in AngloAmerican Bankruptcy Proceedings"” (1998) 131 U. Pa. L. Rev. 69.

David Gray Carlson, "The Chapter 13 Estate and Its Discontents" (2009) 17 Am. Bankr. Inst. L. Rev. 233.

Geoffrey M Collins "Negative Equity and Purchase Money Security Interests Under the Uniform Commercial Code and BAPCA" (2009) 95 Cornell L. Rev. 161.

John Eggman, Katherine Porter and Tara Twomey. "Saving Homes in Bankruptcy: Housing Affordability and Loan Modification" (2008) Utah L. Rev. 1123.

Daniel Farber, "What (if Anything) Can Economics Say about Equity?" (2003) 101 Mich. L. Rev. 1791.

David Hahn, "Personal Bankruptcy in the $21^{\text {st }}$ Century: Emerging Trends and New Challenges: Velvet Bankruptcy" (2006) 7 Theoretical Inq. L. 533.

Steven Harris, “A Reply to Theodore Eisenberg's Bankruptcy Law in Perspective" (1982) 30 UCLA L.R. 364.

John Hicks, "The Foundations of Welfare Economics" (1939) 49 Economic Journal 696.

Thomas Jackson, “The Fresh Start Policy in Bankruptcy Law” (1984-1985) 98 Harvard L.R. 1393.

Nicholas Kaldor, "Welfare Propositions of Economics and Interpersonal Comparisons of Utility” (1939) 49 Economic Journal 549. 
Jason Kilborn, “La Responsabilisation de 1'Economie: What the United States Can Learn From the New French Law on Consumer Overindebtedness" (2005) 26 Mich. J. Int'l L 619 .

Jason Kilborn, "Out with the New, In with the Old: As Sweden Aggressively Streamlines Its Consumer Bankruptcy System, Have U.S. Reformers Fallen Off the Learning Curve?” (2007) 80 Am. Bankr. L.J. 435.

Jason Kilborn, "Still Chasing Chimeras But Finally Slaying Some Dragons In the Quest for Consumer Bankruptcy Reform” (2012) 25 Loy. Consumer L. Rev 1.

Jason Kilborn, "The Innovative German Approach to Consumer Debt Relief: Revolutionary Changes in German Law, and Surprising Lessons for the United States" (2004) 24 Nw. J. Int'l L. \& Bus. 257.

Jason Kilborn, "Twenty-Five Years of Consumer Bankruptcy in Continental Europe: Internalizing Negative Externalities and Humanizing Justice in Denmark" (2009) 18 Insol. Rev. 155.

John King, "Moving beyond the hard-easy tug of war: a historical, empirical and theoretical assessment of bankruptcy discharge" (2004) 28 Melbourne U. L.R. 654.

Donald Korobkin, "Rehabilitating Values: A Jurisprudence of Bankruptcy" (1990) 91 Columbia Law Review at 739.

Katherine Porter \& Deborah Thorne, "The Failure of Bankruptcy's Fresh Start" (2006) 92 Cornell L. Rev. 88.

Joseph Spooner "Long Overdue: What The Belated Reform of Irish Insolvency Law Tells Us About Comparative Consumer Bankruptcy" (2012) 86 Am. Bankr. L.J. 243.

Charles Tabb, "The Scope of the Fresh Start in Bankruptcy: Collateral Conversions and the Dischargability Debate" (1990) 59 Geo. Wash. L Rev. 56.

Israel Treiman, "Majority Control in Compositions: Its Historical Origins and Development" (1937) Va. L. Rev. 507.

Michelle J. White and Ning Zhu, "Saving Your Home in Chapter 13 Bankruptcy" (2010) J. Legal Stud. U. Chi. 33. 
Mark S. Zuckerberg and Amanda K. Quick, "Stripping in Bankruptcy" (2012) 56 Res Gestae Indiana Bar Journal (Indiana State Bar Association December 2012) 39.

G Parliamentary and Government Materials

$1 \quad$ Australia

Commonwealth of Australia, Parliamentary Debates, Senate, 25 March 1980, 999 (Gareth Evans).

H Reports

$1 \quad$ New Zealand

Insolvency and Trustee Service, Insolvency Statistics and Debtor Profile Report for the Year 1 July 2012 to 30 June 2013, (Insolvency and Trustee Service, New Zealand, 2013).

Ministry of Economic Development Draft Insolvency Law Reform Bill Discussion Document Wellington, (2004).

Ministry of Economic Development Insolvency Law Review: Tier One Discussion Documents (Ministry of Economic Development, Wellington, 2001).

New Zealand Law Commission, "Insolvency Law Reform: Promoting Trust and Confidence" An Advisory Report to the Ministry of Economic Development, Study Paper 11, Wellington, (2001).

$2 \quad$ United States

Bankruptcy Judges Division, Administrative Office of the United States Courts Bankruptcy Basics (Administrative Office of the United States Courts, 2011).

I Dissertations

$1 \quad$ New Zealand 
Jane Penney, Discharge of Bankrupts: Recent Developments (Law Faculty Victoria University, Wellington, 2008).

\section{J Internet Materials}

Brookers Online, "Commentary Insolvency Law \& Practice" Brookers Online $<$ http://www.brookersonline.co.nz.helicon.vuw.ac.nz/databases/modus/lawpart/statute s/ACT-NZL-PUB-Y.2006-55 BDY PT.4 SPT.1 SG.!101 S.298?si=57359 > last viewed 26 February 2014.

Street Legal, "Introduction to Bankruptcy Notices" <http://www.legalstreet.co.nz/bankruptcy.html>. 